7084

12 United States

Agriculture

Forest Service

Miscellaneous

Publication No. 1462
A History of Forestry Research in the Southern United States

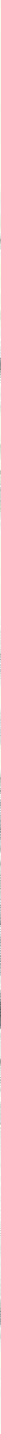



Historic, archived document

Do not assume content reflects current scientific knowledge, policies, or practices. 
The Forest Service, in collaboration with State forestry agencies, forestry schools, forest industries, and other forestry interests, has prepared a comprehensive analysis of the timber situation in the 12 Southern States. This analysis has been published as Forest Resource Report No. 24, "The South's Fourth Forest: Alternatives for the Future." The present handbook is a supplement to that document.

"The South's Fourth Forest" is available for purchase from the National Technical Information Service, 5285 Port Royal Road, Springfield, VA 22161 (in both paperbound and microfiche). 
United States

Department of

Agriculture

Forest Service

Miscellaneous

Publication No. 1462

March 1989

\section{A History of Forestry Research in the Southern United States}

By H.R. Josephson ${ }^{1}$

1 H.R. Josephson is a former director of the Division of Forest Economics and Marketing Research of the USDA Forest Service in Washington, DC. 


\section{Preface}

The great progress in southern forestry during the past half century must be attributed in part to research scientists who provided scientific knowledge and practical technology for forest protection, management, and utilization. Research has pointed the way to better control and use of fire and to more effective methods for regenerating desirable tree species. Improved methods for managing forest lands for timber and other uses, better techniques for controlling insects and diseases, and improved ways of producing and using forest products also have stemmed from a wide variety of research investigations.

The combination of research and action programs of Federal, State, and industrial forestry organizations has been a major factor in improving the South's timber supply situation. Timber growth and inventories have shown impressive gains over recent decades. Pulp and paper and other forest industries have expanded steadily. Forest uses for livestock, wildlife, and recreation have been improved. Through such developments, forestry continues as the keystone of the economy in many parts of the South.

Many scientists and practical forest managers have contributed to the growth of forestry knowledge and new technology. In earlier years, most forest researchers in the South were employed at the Southern and Southeastern Forest Experiment Stations of the USDA Forest Service. But in recent decades, expanding staffs of forestry schools and other research organizations in the region have also made substantial contributions to forestry knowledge.

Developing successful forestry practices is typically the result of integrating bits of knowledge contributed by many different people, through formal research, observation, and empirical testing of new ideas. Because the historical literature on southern forestry is extensive and varied, giving appropriate credit to individuals is difficult if not impossible. The magnitude of the task of citing all contributors may be illustrated by the fact that in the 
preparation of certain major publications mentioned later, authors reviewed and abstracted as many as a thousand reports and articles for each.

The scope of this document is necessarily limited, and I regret that recognition could not be given to many who have added to the fund of knowledge relating to southern forestry.

This brief history was prepared as part of a comprehensive "southern timber study" being conducted by the USDA Forest Service in cooperation with State forestry agencies, universities, and forest industry groups in the South. An earlier draft of this report was reviewed by research scientists and others familiar with conditions and historical events in the South. Their very useful comments and suggestions are gratefully acknowledged. 


\section{Contents}

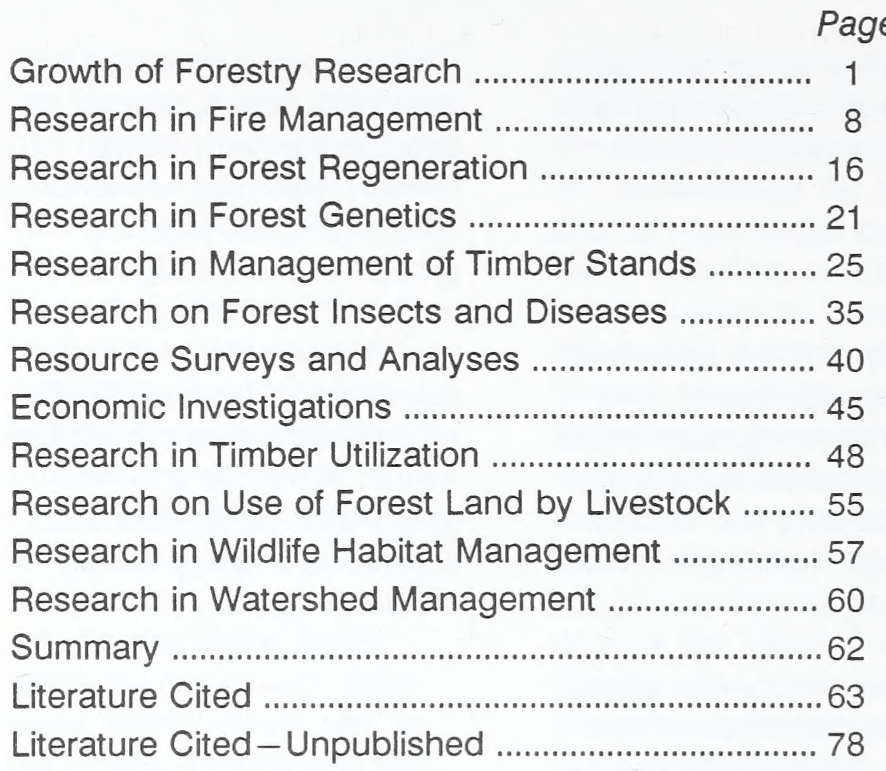




\section{Growth of Forestry Research}

Formal research in forestry in the South may be said to have begun about 1921, when the USDA Forest Service established the Southern Forest Experiment Station in New Orleans, LA. ${ }^{2} \mathrm{~A}$ visitor to the station at this time would have found a director, R.D. Forbes - a Yale forestry graduate and former State Forester of Louisiana-plus a staff of four professionally trained foresters and one clerk. This group was given the responsibility for forestry research in southern pine types extending from Texas through South Carolina.

Also in 1921, the Appalachian Forest Experiment Station was established at

\footnotetext{
2 A fascinating account of the early years of the Southern Station is contained in "A Biased History of the Southern Forest Experiment Station Through Fiscal Year 1933," by Philip C. Wakeley Wakeley 1964 unpubl.). Additional recollections appeared in the Journal of Forest History in April 1976. Over the years, annual reports on research accomplishments, plus occasional bibliographies, have provided a picture of the continuing growth in investigations and research findings of the experiment stations.
}

Asheville, NC, under director E.H. Frothingham, with an even smaller staff of three technical foresters and a clerk. Originally assigned responsibility for research in the hardwood forests of the southern Appalachians, after World War II this station was renamed the Southeastern Forest Experiment Station and given research responsibilities in both pine and hardwood types from Florida through Virginia.

Prior to the establishment of these experiment stations, some limited research pertaining to southern forestry had been conducted by the U.S. Bureau of Forestry (later the Forest Service) and by some State agencies, but funds for such work were very limited. Some early studies dealing with lumber seasoning and preservatives for railway ties, for example, applied to southern pine species. And other national studies of forest resources and a few local reports on the timber and naval-stores industries provided some general knowledge of southern forest conditions and problems. 
The early research efforts of the Forest Service were aimed primarily at improving conditions on privately owned forest lands. Although Federal and State lands were of limited significance in the South, initial research was, nevertheless, closely linked to the administrative arm of the Forest Service. In 1915, the Service established separate status for research, centered in a new branch of research, with field stations reporting directly to the head of research in Washington. But policy and scientific differences between administrations and researchers continued for some time in the case of fire management (Schiff 1962).

The initial program of research at the Southern Station was ambitious for a small staff. One of the key assignments involved studies of growth and yield in second-growth stands of the four major southern pines, conducted under the technical guidance of Donald Bruce in the Washington Office. This work led to Miscellaneous Publication 50 , containing "normal" yield tables for unmanaged pine stands (U.S. Forest Service 1929). Although these yield tables were modified by later studies, this publication undoubtedly contributed greatly to wider understanding of southern pine growth potentials and forestry opportunities.

Early studies of harvesting and reproduction of longleaf pine were begun in Louisiana under E.W. Hadley. At McNeill, MS, studies by W.G. Wahlenberg and coworkers determined the interacting influence of cattle grazing and fire on tree regeneration and forage for livestock. At Starke, FL, empirical studies by Lenthal Wyman searched for better methods of producing naval stores. Research on effects of thinning in even-aged stands of loblolly and shortleaf pine was started at Urania, LA, under W.R. Hine. General studies of "forestation" and fire impacts by Phil Wakeley were also included in the Station program. The Experiment Station at Asheville was largely concerned with studies of mountain hardwoods, but L.I. Barrett and F.I. Righter conducted some thinning studies in loblolly 
and shortleaf pine stands in the Piedmont.

The 1920's saw a steady expansion of these small station staffs. By 1927, the Southern Station roster had grown to 23 employees.

Passage of the McSweeney - McNary Forest Research Act of 1928 gave further impetus to research in southern forestry through expanded funding and staffing. New programs in the New Deal period of the 1930's brought additional finances to support a growing research staff and a broadened variety of studies. In this period, the Civilian Conservation Corps also made valuable contributions by building access roads to experimental forests, constructing headquarters buildings, and furnishing labor for installing experimental plots.

The new recruits who joined southern forest research organizations in this period came from several forestry schools, "bringing new interests, specialties, techniques, and enthusiasms that helped create a stimulating intellectual climate" (Wakeley 1964 unpubl.).
Continuing growth brought the budget of the two southern forest experiment stations to nearly $\$ 350,000$ by the outbreak of World War II.

During the war years of the 1940's, available research personnel were largely occupied with emergency projects designed to provide information and other assistance to wartime agencies. Monthly surveys of lumber production and special studies of equipment and material needs of the forestproducts industries furnished essential data for defense programs. Utilization specialists supplied technical information to loggers, millmen, and others in the forest industries.

These specialists subsequently staffed the postwar "Forest Utilization Service" at both southern forest experiment stations as part of a nationwide effort to relate utilization research like that conducted at the Forest Products Laboratory at Madison, WI, more closely to the needs of forest industries. In the late 1960's, these programs of "technology transfer" from research to field applications were 
shifted to the State and Private Forestry branch of the Forest Service.

Following the end of World War II, the Forest Farmers Association Cooperative, then located at Valdosta, GA, spearheaded a drive for more adequate programs of forestry research to meet the growing demands for information on use and management of southern forests. The resulting expansion of research by the Forest Service in the South was conducted to a large extent through about 20 research centers, with investigations generally oriented to local or subregional forest types and problems. With the aid of local advisory committees and cooperators from forest industry, forestry schools, and other groups, these centers became major forces in the technical advance of forestry in the South.

In the 1950's emphasis shifted from such geographic orientation to a more functional approach, with research in depth on problems that could have broad regional relevance. Also beginning in this period, scientists were provided with modern laboratory facilities and support staffs at a number of experimental forests and other locations, such as the Southern Institute of Forest Genetics at Gulfport, MS, and the forest fire laboratory at Macon, GA. With increasing frequency, Forest Service researchers were located at universities to foster closer cooperation with university scientists.

As part of a reorganization of the U.S. Department of Agriculture in the 1950's, research on forest insects was transferred from the Bureau of Entomology and Plant Quarantine to the Forest Service, and research on forest diseases was moved from the Bureau of Plant Industry, Soils and Engineering to the Forest Service. Researchers from these agencies had long cooperated with experiment station scientists and readily became part of the Forest Service organization.

Since the mid-1960's the experiment stations of the Forest Service have been administered under a sys- 
tem using assistant station directors, each responsible for a portion of the total research program or for investigations in specific geographic areas. The Southeastern Station organized its research in some 23 "work units" at 12 separate locations, plus other staffing including research and development programs, pioineering units, and special research units (Southeastern Forest Experiment Station 1983). The Southern Station designated 21 similar work units to carry out its research.

Research work units have responsibility for solving specified problems, selected with the assistance of land managers, public agencies, environmental groups, and other research organizations. Many of these research units are located on university campuses, where there are opportunities to work with faculty from forestry schools and other departments.

Funding for research at the two Forest Service forest experiment stations in the South reached a total of about \$25 million in fiscal year 1981. In the following 3 years, funding in constant dollars dropped somewhat more than 10 percent.

Staffing in 1980 totaled 244 scientist years (USDA Forest Service 1982b). More than half of these scientists worked primarily with the southern pines, while the remainder dealt mainly with problems relating to hardwoods, particularly in bottomland areas.

\section{Forestry schools in the} South also began studies of forest and range problems in the 1930's, supplementing a very limited program of forestry-related research at State agricultural experiment stations. In the years after World War II, university research programs expanded greatly, both at the 14 schools or departments in the South and in other departments. University research programs have been supported primarily by State funds, although significant assistance also has been provided through the

Mclntire-Stennis Forestry Research Act of 1962, which authorized Federal grants for forestry research by State universities. Coopera- 
tive aid grants from the Forest Service also helped in educating graduate students as well as supporting faculty research. The total funds available for university research in 1980 amounted to about $\$ 24.7$ million, according to unpublished data from the USDA Cooperative State Research Service, and staffing in 1980 totaled 187 scientist years.

Among other organizations contributing to forestry research was the Georgia Forest Research Council, which, under the leadership of R.E. Ruark, acted as a catalyst for many investigations. It also constructed the forest fire laboratory at Macon, GA, for use by the Forest Service in carrying out fire studies. The Tall Timbers Research Station in Florida became well known for studies in fire ecology and for sponsoring many symposia on various forestry problems. The Tennessee Valley Authority published many studies dealing with such topics as industrial development and management of forests and related resources.
Forest industries also made major investments in forestry research. For example, in the 1950's, the International Paper Company established a research center at Bainbridge, GA, where scientists carried out cooperative studies of forest diseases, prescribed burning, and stand improvement under the direction of Charles Driver and C.J. Perkins. Research staffs of other companies such as Weyerhaeuser, Union Bag [now Camp], and West Virginia Pulp and Paper [now Westvaco] likewise conducted many studies of forestry problems. Forest industries played a leading role in cooperation with equipment manufacturers in developing and testing logging and processing equipment and technology.

In the South, the forest industries also have frequently provided funds for such Federal and State research as the forest survey and furnished experimental forest areas for studies in timber management. Industry members of advisory committees helped develop and guide research programs of public agencies. 
And industrial foresters deserve much credit for the practical testing of new ideas and alternative techniques for protection, management, and utilization of southern forests.

With the substantial growth in numbers of research scientists and publications over the past several decades, the need for coordination in research planning and dissemination of research findings has grown accordingly (e.g., USDA Forest Service 1982b). Both the Forest Service and other agencies have issued a wide variety of research publications ranging from brief notes to comprehensive handbooks and monographs. Many scientists have published extensively in specialized technical journals. And numerous findings have been reported in such publications as the Southern Lumberman, the Forest Farmer, the Journal of Forestry, and the Southern Journal of Applied Forestry. Another response to the growth in programs and publications has been the increasing use of symposia, workshops, conferences, and working groups as means of coordinating research planning and integrating the findings of scientists in different organizations. Participation of members of action agencies in these sessions has also provided an effective means of getting research results into practice with minimum delays. 


\section{Research in Fire Management}

The selection of research studies at the newly established forest experiment stations in the South to a large extent reflected the condition of forest and range lands in the region and the related problems of forest owners and timber operators. By the end of World War I, many people considered southern forest to be near extinction (White 1961). Lumbering had taken a heavy toll on the vast areas of State and Federal timberlands released for unrestricted sale and lumbering in the 1800's. The end of the virgin forest was at hand, with much of the deforested land burned over and nonstocked with timber trees. Many rural residents believed that annual woods burning was necessary to improve livestock grazing and eliminate pests. Their self-prescribed fires effectively prevented reestablishment of pines on many cutover areas Southwide. Both the attitudes of southerners toward fire and flammability of the luxuriant "rough" of ground vegetation offered major challenges to pioneers in fire control.
With the rise of the conservation movement in the early years of this century, fire exclusion on southern pine forests became the policy of most foresters and conservationists. Publications dealing with fire in the South were largely preoccupied with the evils of widespread and uncontrolled fire, as in the writings of Pinchot and others. But because such "educational" efforts were not very successful, the Forest Service and State forestry organizations came to rely on legal prohibitions as the only feasible way to control wildfire. Forest fuels built up in the absence of frequent burning, and the result was many damaging wildfires and intensified conflicts with local residents.

In this early period, observers such as H.H. Chapman of Yale University and Austin Carey of the USDA Forest Service aroused the forestry profession by eloquent and persistent arguments that intentional burning of the woods at proper intervals would be a better solution to the fire problem. As early as 1911, 
a forest administrator in Florida, I.F. Eldridge, also broke with convention by using fire to reduce harzardous fuels in longleaf pine stands. Roland Hayes,

a botanist at Alabama Polytechnic Institute, observed that selective periodic fire served to forestall hardwood succession. And in Louisiana, lumberman Henry Hardtner began to use what he called controlled burning in the regeneration and management of longleaf pine. ${ }^{3}$

The issue of fire exclusion versus controlled burning in southern forests necessarily became a subject for forest researchers as well as forest administrators. Fire was a central problem in the regeneration of

3 The differing viewpoints and extensive conflicts over use of fire in southern forests have been described in considerable detail (Pyne 1982).

4 These have been enumerated in an unusually interesting bibliography and commentary on fire ecology and fire use in the pine forests of the South by A. Bigler Crow (1982). Another bibliography by Cushwa (1968) also covered the period $1920-66$. cut-over stands, in protection of plantations and young natural stands, and in control of unwanted vegetation, as well as a means of enhancing livestock grazing and wildlife habitat. In the past five or six decades, a large number of studies of different aspects of wildlife and prescribed burning consequently were undertaken through the South. ${ }^{4}$

Early studies by H.H. Chapman in the 1920's and subsequently by Forest Service researchers such as Phil Wakeley, Paul Siggers, and W.G. Wahlenberg demonstrated that in longleaf pine forests, controlled fires not only help avoid destructive wildfires but also retard the brownspot needle disease.

Trees in burned areas showed earlier height growth and better stand development than trees in unburned stands. Fungicidal control of brownspot also was found to be effective but has been considered useful primarily in tree nurseries. Studies by Heyward and Barrette (1934) determined that prescribed fires do not 
adversely affect soil chemistry or soil fauna. In later years, other evaluations of impacts of fire on nutrient cycling (e.g., McKee and Lewis $1982 a$ and b) gave similar reassurance to advocates of controlled fire.

Another early observer of the role of fire in management of livestock was S.W. Greene, a range specialist in the Bureau of Animal Husbandry, who urged judicious use of fire for range improvement. His studies showed that burning increases the palatability and nutritive value of southern rangelands, and that cattle gain more weight in annually burned ranges than on unburned areas (Greene 1931). Also in 1931, H.L. Stoddard, working with the U.S. Biological Survey, published a notable study on the bobwhite quail that showed the value of controlled fire in quail habitat management.

In 1933, the Southern Forest Experiment Station summarized a number of investigations in a review of the highly controversial issue of prescribed burning versus fire exclusion. This "fire statement," covering the pros and cons of fire effects, came out firmly on the side of judicious use of fire for both silvicultural and other forest management purposes (Crow 1982).

In subsequent years, E.L. Demmon and others provided much additional information on the occurrence and silvicultural impacts of fire. H.H. Chapman's work with loblolly pine in Arkansas and Louisiana (1942) paralleled his earlier informative studies of fire in longleaf pine management. Studies by Wahlenberg and coworkers at McNeill, MS, confirmed the earlier studies by Greene on benefits of prescribed fire on forest ranges. Other investigators such as C.E. Bickford, J.W. Squires, and R.D. McCulley developed further recommendations for protective burning in longleaf and slash pine forests. L.E. Chaiken and I.T. Haig determined that fire could be used effectively in other pine types to control unwanted hardwoods. Effects of fire on oleoresin yields of longleaf and slash pines were described by V.L. Harper (1944). And W.G. 
Wahlenberg's definitive work on longleaf pine (1946) cited many research findings on the beneficial role of fire for silvicultural purposes.

Since the 1940's, dozens of scientists have issued reports on various aspects of prescribed burning (Crow 1982). Research by E.R. Ferguson, R.W. Cooper, E.V. Brender, T. Lotti, and others demonstrated that in pine types other than longleaf, and in pinehardwood forests, prescribed burning is somewhat less effective and more difficult than in longleaf forests but still helps suppress unwanted vegetation and improves grazing and wildfire habitat. In hardwood types, on the other hand, studies revealed serious problems of decay in trees damaged by fire (e.g., Hepting 1935).

Continued concern over effects of repeated fires on soil productivity was answered by studies that revealed little or no adverse impacts on fertility or soil movement (e.g., McKee and Lewis 1982a and b). On the Francis Marion
National Forest in South Carolina, for example, organic matter in surface soils and growth rates of trees both increased slightly following well-conducted burning (Cooper 1973). Prescribed burning for seedbed preparation, followed by clearcutting, also resulted in less runoff and streamflows than reported for mechanical means of site preparation (Douglas and others 1982).

The value of prescribed fire for improving forage for livestock in the coastal plain of the South has been supported by many observations and studies following the early work at McNeill, MS (Wahlenberg and Reed 1939). In a series of studies in Georgia, H.H. Biswell and coworkers demonstrated that fire was a necessity for improvement of forest ranges and beef cattle production. The benefits of prescribed burning for livestock production in other parts of the South were subsequently described by other well-known range scientists such as R.S. Campbell, J.T. Cassidy, L.K. Halls, B.L. Bouthwell, and W.O. Shepherd. Other 
studies evaluated the effects of different seasons and frequencies of burning on herbage production and tree growth (e.g., Grelen 1983). The early work of H.L. Stoddard with the bobwhite quail indicated how fire can be used to perpetuate one of the South's premier game species. In more recent years the accumulating knowledge of beneficial effects of fire on wildlife habitat has been summarized in various publications and symposia (e.g., Wood 1981 and Kormarek 1981).

Fire research efforts of agencies other than the Forest Service have notably included work by the Tall Timbers Research Station at Tallahasee, FL. Under the leadership of E.V. Kormarek, Sr., this organization conducted numerous symposia on the complex influences of fire on plant and animal environments and the use of fire in land management. Fire ecology conferences starting in 1962, and published proceedings resulting therefrom have provided much knowledge on the ecology of prescribed burning and its impacts on wildlife.

Much of the accumulating information on prescribed burning was summarized in a notable symposium conducted in Charleston, SC, in 1971 (USDA Forest Service 1971). Another treatise on prescribed burning was issued in an Environmental Protection Agency source document (Chi and others 1979). Major textbooks on fire, including an initial work by A.D. Folweiler and A.A. Brown in 1939 and a definitive text ("Forest Fire Control and Use") published by K.P. Davis in 1959, contained considerable information on prescribed burning. Many local how-todo-it manuals, with specific guidelines, also have been issued by different agencies and industry organizations.

With the accumulation of research findings and empirical evidence of favorable effects of prescribed burning, particularly in the coastal plain region and lower Piedmont, the Forest Service and State forestry agencies in the early 1940's reversed a long-standing 
policy of fire exclusion and, along with many landowners, adopted prescribed burning programs. In the mid-1970's, for example, controlled burning was carried out on more than 2 million acres annually on industrial, public, and other ownerships in the South (Johansen and McNab 1982)

Today, prescribed burning is recognized as an essential, relatively inexpensive, and effective tool of management in the pine forests of the South, with benefits including fire-hazard reduction, site preparation for forest regeneration, control of undesirable vegetation, and improvement of habitat for wildlife and livestock. Nevertheless, members of the public and environmental groups express considerable concern that smoke from woods fires contributes seriously to air pollution. Public pressure and legislation threaten to curtail or eliminate intentional woods burning, particularly near highways, airports, and population centers.

Research conducted in response to such concerns has indicated that smoke from prescribed woods burning does not produce highly damaging sulfur oxides, and nitrogen oxides are produced only with high fire temperatures (Cooper 1973). Also, by reducing the incidence of wildfires, total emissions from forest burning may be reduced.

Scientists at the fire laboratory in Macon, GA, have identified ways to minimize smoke impacts from prescribed burning and have issued recommendations for actions to ensure that smoke does not reach sensitive areas (Southern Forest Fire Laboratory 1976). Prescriptions, based on indepth treatment of smoke, fuels, emissions, smoke transport, and dispersion, outline a system for predicting and modifying smoke concentrations from prescribed fire. As an aid in starting prescribed burns when conditions are most favorable, methods have also been developed for dropping jellied fuels of potassium permanganate from aircraft. 
Because of factors such as cost and concern over air pollution, prescribed burning is not universally practiced throughout the South, and control of wildfire remains a serious problem. In 1978, for example, more than 130,000 wildfires burned some 3.2 million acres of forest land in the 11 Southern States.

\section{A continuing program of research aimed at control of wildfire has, therefore, long been considered} essential, and this research has led to significant improvements in prevention and suppression of wildfire. Early research by G.M. Jemison, R.M. Nelson, and T.T. Keetch at the Southeastern Station, for example, helped develop improved systems of fire-danger rating, a matter of great importance to forest administrators. Improved understanding of fire behavior and damage stemmed from the work of G.M. Byram and coworkers in studies involving physics, chemistry, meteorology, and new forms of operations research.

Other investigations at the southern fire laboratory in Macon, GA, have included mathematical and physical models of free-burning fires and techniques of simulation that provide an improved basis for fire planning.

Studies of fire retardants and aerial bombing techniques using air tankers to drop water and chemicals on fires have helped improve fire control. Development and widespread use of fireplows in constructing firelines for control of both wildfire and prescribed burns, pioneered by such men as Art Shepherd, have been of tremendous value to firefighters in the relatively flat terrain of the South. Scientists have also developed better techniques for local fire-weather forecasts (e.g., Paul and Clayton 1978), useful both for timing of prescribed fires and for presuppression activities. In 1979 , a national fire effects workshop (USDA Forest Service 1978a) brought together much of the available information on the effects of fire on fuels, soils, air, water, and fauna and flora.

In the area of fire prevention, studies have developed a 
better understanding of attitudes of different groups toward fire and possible ways to modify the behavior of fire setters. Psychological studies provided information on the many and varied reasons why rural residents practice woods burning (Shea 1940, Dunkelberger and Altobellis 1975). Researchers at universities in Louisiana and Mississippi, including A.W Baird, A.L. Bertrand, B.E. Griessman, T. Hansborough, and H.F. Kaufman, together with W.L. Doolittle and others in the Forest Service, conducted a series of studies of fire-prevention factors and techniques (e.g., Bertrand and Baird 1975). Recommendations flowing from these studies have stressed, for example, the importance of personal contact in communicating fireprevention messages (e.g., Doolittle and Welch 1974).
It seems clear that the development and application of knowledge regarding fire impacts, control, prevention, and prescribed uses have had major effects on the forest situation in the South. Fire agencies have been able to reduce acreage burned and damages from wildfire while saving on fire-control costs. Losses of timber and other resources have been greatly reduced, with consequent increases in timber growth and encouragement of investments in timber growing. Stand composition in southern forests has been widely modified through prescribed burning to favor pine over unwanted hardwoods. And values of wildlife, livestock production, and recreation undoubtedly have also been enhanced through improved fire management. 
Along with the need for protection of southern forests from fire, the problem of restocking cutover and burned pine lands was likewise of critical importance for forest recovery. But natural regeneration was hindered by the lack of seed sources in many areas, by competition from hardwoods, and in the case of longleaf pine by freeroaming hogs that destroyed most seedlings. In producing seedlings for plantations, foresters faced many questions of seed source, nursery practice, and ways of controlling diseases such as brownspot in longleaf pine and fusiform rust in slash and loblolly pines.

Early studies on regeneration of southern pines, conducted by Phil Wakeley and L.J. Pessin and coworkers, were aimed at establishing guides for selection of nursery stock to be planted in the field. Development of productive tree nurseries, tests of planting methods, spacing studies, and determination of causes of seedling mortality rounded out these early investigations.

These initial reforestation studies conducted by researchers were overshadowed, according to Wakeley (1964 unpubl.), by the practical observations and practices of F.O. Bateman, chief ranger of the Great Southern Lumber Company at Bogalusa, LA, who developed and directed a company program of tree planting and natural regeneration that proved to be one of the most comprehensive and successful reforestation programs of all time. Also in Louisiana, Henry Hardtner, president of the Urania Lumber Company, pioneered practical natural reforestation by the simple yet effective steps of protecting forests from wildfire and by fencing company lands against the omnipresent razorback hog, a scourge that outranked fire in its ability to destroy seedlings of longleaf pine. Among other companies starting regeneration programs in the earlier years of this century were the Crossett Lumber Company in Arkansas and the 
Chesapeake Corporation of West Point, VA (Clepper 1971).

Information gained from early regeneration studies and the extensive planting trials at Bogalusa, LA, was summarized in a technical bulletin on artificial regeneration in the southern pine region (Wakeley 1935), issued just in time to guide the widespread treeplanting efforts of the young men in the Civilian Conservation Corps camps established Southwide in the 1930's. Planting guidelines thus made available stressed the importance of proper geographic seed source, the need to consider soil type and characteristics in selecting species for planting, criteria for seedling selection and planting methods, and fencing requirements.

Continuing studies of pine regeneration led in later years to issuance of other major publications on planting the southern pines (Wakeley 1951 and 1954). In 1965, the Georgia Forest Research Council also published the 360-page book "A Guide to Loblolly and Slash Pine Plantation Management in the Southeastern United States," with contributions from some 24 researchers (Wahlenberg 1965). Such documents were widely used by forestry organizations to guide reforestation efforts during the postwar tree-planting boom in the South.

Many other research contributions have enhanced the effectiveness and efficiency of regeneration practices. The need to protect seedlings in nurseries from diseases such as fusiform rust quickly led to a search for control methods. As a result of work by scientists such A.A. Foster (1961) and S.J. Rowan (1979), chemicals like ferbam, applied under specific schedules, were found to be effective in protecting nursery seedlings. Other studies found that applying benomyl, a systemic fungicide, to the roots of pine seedlings before planting reduced brownspot disease, increased survival, and stimulated early height growth. Tests of various fumigants showed that ethylene dibromide could provide practical control of 
the black root rot, with dramatic increases in production of nursery stock. Guides for nursery management based on such research have been summarized in a southern pine nursery handbook (USDA Forest Service 1984a).

Scientists have also known for some time that tree roots and certain fungi form a sybiotic association called mycorrhizae. Studies by D.H. Marx, J.L. Ruhle, and their associates demonstrated that some fungi are more beneficial than others in improving seedling survival and growth. As a followup to this research, cooperative work with Abbott Laboratories and participating nurserymen led to development of effective techniques for large-scale production and use of preferred inoculum in commercial production of container-grown and other seedlings (Marx and others 1982).

The search for improved methods of obtaining desirable forest regeneration also included the direct seeding of pine in lieu of nursery production and field planting of seedlings. Effective procedures including use of bird and animal repellents, seedbed preparation, and timing of seeding were developed, notably at the Alexandria, LA, research center in cooperation with the U.S. Fish and Wildlife Service (e.g., Mann and Derr 1964). Control of stocking has been somewhat difficult with direct seeding, however, and use of repellent chemicals has heen challenged on environmental grounds. Foresters have also pointed out that genetically improved seed may be used more efficiently in producing nursery stock.

Container-grown seedlings also have been used effectively in the South (e.g., Barnett and McGilvray 1981). Studies have shown that costs of producing container stock are relatively low, and site requirements for producing containergrown seedlings are minimal (Guldin 1983). Container seedlings also can be planted over a longer season, survival rates are relatively high, and managers can make efficient use of genetically improved seed. Getting such research 
results into use in the production of seedlings has been facilitated through issuance of handbooks and through southern nursery conferences (e.g., Lantz 1984) and a southern containerized forest tree seedling conference (e.g., Guldin and Barnett 1981).

Research on reforestation has undoubtedly contributed greatly to the extensive tree-planting programs carried out in the South. By 1979, some 20 million acres of southern pine plantations had been established, with new plantings covering more than 1.5 million acres annually.

Forest researchers also have given considerable attention to methods for obtaining natural regeneration of the southern pines.

Findings indicate that several practical methods are available (e.g., Lawson 1979). A 36-year study of four silvicultural methods in loblolly and shortleaf pine stands showed that adequate and low-cost regeneration can be obtained with seed-tree, clearcutting, selection, and diameter-limit cutting. Difficulties in regen- erating longleaf pine led many foresters in the 1950's and 1960's to plant alternative species such as slash pine. However, research developed new guidelines for use of the shelterwood system, and longleaf has regained an important role in pine management (Croker and Boyer 1975).

Management guidelines based on the findings of such research have been widely used both by industrial foresters and by public service foresters in providing technical assistance to landowners who are reluctant or unable to invest in systems of clearcutting and planting. Natural regeneration is a low-cost method but provides limited control of stocking, takes more time, and provides less opportunity for genetic improvement than planting selected seedlings.

In the case of southern hardwoods, considerable research also has been conducted both on ways of obtaining natural regeneration of preferred hardwoods and on establishment of plantations, particularly of cottonwood in the Delta 
area. The work of L.C.

Maisenhelder, J.S.

McKnight, F. Bonner, R.L.

Johnson, and E.C. McGee, for example, has provided guidelines for obtaining regeneration of desirable species, through both appropriate cutting practices and establishment of plantations of selected species.

Underlying the many practical recommendations that have been developed for regenerating both pines and hardwoods in southern forests are additional studies by many different researchers. These have covered various aspects of seed collection, seed germination, nursery practices, insect and disease control, care of planting stock, site preparation, and field planting procedures. And much information on forest regeneration also has been obtained as part of research on the genetic selection and improvement of forest trees and management of forest stands. 


\section{Research in Forest Genetics}

Two major aspects of regeneration research are tree and seed selection and the longer term task of breeding superior trees. Over the past several decades, genetic improvement of the southern pines has evolved from an idea in the minds of farsighted scientists to an integral part of forest management.

As early as the 1920's, P.C. Wakeley and others undertook research to determine the comparative survival and growth of southern pines originating from different places and parent lines. These and many subsequent studies soon demonstrated the importance of genetic selection to obtain seed from appropriate areas and parent trees, and to select highquality nursery stock for field planting. Selections of longleaf pines for example, turned up individual trees of high resistance to the brownspot needle disease. These trees have yielded open-pollinated progeny with considerable resistance to brownspot, and intercrosses have yielded highly resistant offspring (Snyder and Derr 1972).

Other progeny tests of selected superior trees of longleaf pine confirmed observations that trees from gulf coast sources were superior in survival and growth to trees from elsewhere (Bey and Snyder 1978). Family variation within a region proved to be large enough to permit additional genetic gains. And progeny of crosses of elite trees showed higher survival, less brownspot, and more wood volume than average trees.

Tree-improvement work with slash pine began as early as 1941 at Olustee, FL, with the aim of developing trees with high gum yields for the ailing gum naval stores industry. The finding that individual trees varied greatly in gumyielding ability was a major stimulus to efforts to select and breed superior trees. Ensuing research by H.L. Mitchell, C.R. Gansel, and others led to establishment of "turpentine" seed orchards consisting of strains of pines with high gum 
yields. The best of such trees have produced about twice as much gum as average trees and significantly more wood volume than woods-run trees.

Other research with slash pine, conducted by R.J. Dinus, F.F. Jewell, H.R. Powers, P.V. Siggers, G.A. Snow, P.C. Wakeley, and O.O. Wells, for example, found significant genetic variation in resistance to fusiform rust related to geographic origin and tree parents. Field tests showed the feasibility of sizable improvements in survival and growth by selection of seed from the more resistant parents.

Because of its many desirable properties for wood products and oleoresin, slash pine became the popular choice in many tree-planting programs. Some of the widespread plantings failed, however, and this fact stimulated investigations relating to site relationships, fertilization, drainage, and seed sources. Based on results of studies of such factors, foresters can now make intelligent decisions as to where slash pine can best be established.

Studies of the genetics of loblolly pine also showed much genetic variation in growth and resistance to disease, both by geographic area and by individual trees (Sluder 1980). These genetic studies have notably involved a Southwide seedsource study, begun in 1951 under the sponsoring of a committee on southern forest tree improvement. Committee work, such as cone and seed testing services and publication of proceedings of conferences, has provided much guidance and stimulation both to genetics research and to reforestation programs of southern forestry agencies (e.g., University of Georgia 1983).

Several industry - university cooperative treeimprovement programs also have been developed in the South, at North Carolina State University, the University of Florida, and at Texas $\mathrm{A}$. and $\mathrm{M}$. University. Loblolly pine seed orchards established in the North Carolina State Cooperative, for example, 
show crop gains on 25-year rotations that are estimated to be as high as 12 percent in cubic volume and 32 percent in harvest values (Zobel and Talbert 1984). Rates of return on investments in these seed orchards appear to be as high as 17 to 19 percent after taxes. Yields from first-generation orchards are not great enough to allow most members to meet regeneration needs with improved stock.

As a result of work by these and other scientists, tree improvement is a reality today, and a major phase of forestry in the South is the production and use of seed from pine trees that show superior growth, form, and resistance to disease (e.g., Powers and others 1979). It is estimated that by the early 1980's some 10,600 acres of seed orchards had been established over the South. These include orchards for production of genotypes resistant to fusiform rust, although only limited quantities of seed from such sources are as yet available (Powers and others 1979).
Seed orchard management also has been the focus of related studies that show that proper spacing and fertilization can significantly increase yields of seed. Research in crossbreeding pines has produced a variety of hybrids, including crosses of shortleaf and slash pines, for example, that outperform the parents (Wells and others 1978). Research relating to hardwoods has included development of clones of cottonwoods and hybrid poplars that grow considerably faster than average trees (e.g., Randall 1973).

Much of the information developed on the genetics and breeding of southern pines has been summarized in Agriculture Handbook 471 (Dorman 1976). This major compilation includes material from more than a thousand references on factors affecting flowering and seed production; geographic, racial, stand, and tree variation in genetic characteristics; techniques for enhancing production of superior seed; methods of vegetative propagation; and techniques for breeding new strains of southern 
pines. Agriculture Handbook 587 , on pollen management, covers the collection, processing, storage, and use of pollen from superior trees and provides a synthesis of research and practical experience as to the best methods and equipment for handling tree pollen of southern pines and hardwoods (Franklin 1981). In 1984, Bruce Zobel and John Talbert summarized many years of research on the genetics of southern pines in their major book "Applied Forest Tree Improvement." 


\section{Research in Manage- ment of Timber Stands}

Management of forests for timber products has long been the subject of a major part of the work of forest scientists in the South. Once forests are regenerated, many closely related questions remain. What growth and yields can be expected from natural and from planted stands? How can undesirable hardwoods and other unwanted vegetation be controlled? Will fertilization be effective and economic? Should harvesting be by seed-tree, clearcutting, selection cutting, or other methods?

Such questions faced forest managers for a wide variety of types, sites, and stand and ownership conditions through the extensive and widely varying southern region.

Early studies of southern pine management conducted in the early 1920's by R.D. Forbes and his small staff at the Southern Forest Experiment Station were aimed largely at determining desirable cutting practices in longleaf and other southern pines. Another task was to develop "normal" yield tables for unmanaged pine stands. In this early period, informal studies of so-called practical forestry were also undertaken by a number of southern forest landowners through the crusading efforts of such men as Austin Carey (White 1961). In the 1930's, an expanding program of studies included work by H. Bull, A.L. McKinney, and others to evaluate thinning, pruning, and improvement cutting in loblolly and longleaf pines. Scientists such as W.F. Bond and R.R. Reynolds issued the first in a long series of publications on both silvicultural and financial aspects of southern pine management.

The period prior to World War II also saw the beginning of research on management of bottomland in the South by G.H. Lentz, J.A. Putnam, H. Bull, and others. This work usually featured destructives studies of important timber species to provide an understanding of such attributes as tree charactistics, distribution, and relation to site factors. A 207-page report on trees of the Mississippi bottom- 
lands, prepared in 1932 by Putnam and Bull, won the admiration of an influential audience and its subsequent support for the establishment of a research center and hardwood laboratory at Stoneville, MS.

The postwar period after 1945 saw a major expansion of forest management research in both pine and hardwood types with a wide variety of investigations by many scientists. This work has provided the basis for guidelines that are now available for cultural and harvestig practices for all the major species in all important forest types in the South. Since the mid-1940's more than 190 scientists at the Southern Forest Experiment Station published papers and articles dealing with the culture of timber stands, including silvicultural practices, basic physiology, control of unwanted vegetation, soils and fertilization, and nutrient cycling. At the Southeastern Forest Experiment Station, hundreds of publications on forest management also were issued during these years by more than 200 scientists.

At schools of forestry throughout the South, other research scientists, such as T.S. Coile at North Carolina State University and J.L. Clutter at the University of Georgia, likewise produced much useful information on timber growth and yields and other aspects of forest management. Research staffs of pulp and paper companies conducted and cooperated in many studies of thinning, hardwood control, harvest cutting, forest regeneration, and timber harvesting equipment and methods.

The classification of "timber culture" is necessarily somewhat arbitrary, however, and many other studies relating to fire, regeneration, genetics, or economics also included aspects of cultural practices. Scientists working in different areas of research, as cited elsewhere, have also made significant contributions in the broadly defined field of timber management.

Much of the research in forest management con- 
ducted by the Forest Service experiment stations has been carried out at research centers located in more or less distinct forest types or subregions of the South, and with investigations centered in associated experimental forests.

Thus at Crossett, AR, the Southern Station and the Crossett Lumber Company entered into a cooperative agreement in the 1930's that made possible a world famous series of studies on the Crossett Experimental Forest, an area of loblolly and hardwoods with some shortleaf pine. Other important studies of timber management have been conducted over the years in many parts of the South, but the work at Crossett was among the earliest and produced a great deal of technical knowledge about forest management potentials.

Under the long-term leadership of R.R. Reynolds, a series of treatments under all-aged or "selection" systems of silviculture were started (Reynolds 1980). An initial study of selective logging produced much valuable information on costs, grades, and values of lumber manufactured from second-growth trees. Such findings were of great interest to foresters and to timberland owners looking for guidance in retaining and managing cutover forest lands.

The studies at Crossett demonstrated rapid growth and prompt restocking of residual stands, under management that featured frequent light cuttings to favor the better trees. Tests of truck logging showed that selection management was feasible in the typical immature and understocked stands of the area and could replace conventional but unprofitable railroad logging of such stands. Investigations of controlled burning contributed to the development of local techniques for this important management tool.

The studies at Crossett, demonstrating impressive rates of growth in volunteer stands of second-growth southern pines, greatly promoted the adoption of forest-management practices in many parts of the 
South. As a demonstration area, the Crossett Forest had no peer. Thousands of visitors from the United States and abroad, including many owners of small, nonindustrial properties, have been impressed by the annual harvests of timber from so-called "farm forties," as well as by other demonstrations of high levels of timber growth and profitable forestry practices.

Research on even-aged management was later included in the program at Crossett. C.F. Grano and associates provided comparisons with the demonstrably effective selection methods of management that had long been under intensive study at Crossett. Research has documented advantages of even-aged systems of timber management that are now practically universal on the extensive holdings of pulp and paper companies and other large ownerships in the South.

Studies similar those at Crossett have been undertaken at other research centers and experimental forests in major subregions throughout the South.
Examples include the research center at Alexandria, $L A$, long under the direction of W.F. Mann, Jr., which concentrated on problems of management in the longleaf and loblolly shortleaf pine types. Here such practices as direct seeding, thinning, and plantation management received special attention.

A research center at Nacogdoches, TX, emphasized research on techniques of prescribed burning and management of wildlife habitat. On the Hitchiti Experimental Forest near Macon, GA, studies were mainly directed toward management of loblolly pine in the Georgia Piedmont (e.g., Brender 1973). Scientists at Cordele, GA, and Olustee, FL, working in cooperation with university researchers, developed guidelines for management of slash pine in the coastal plain region (e.g., Bailey and others 1982). At these and other research centers, the research and demonstrations of forestry practices provided fundamental knowledge on the silviculture of all the major southern pine types - information of 
immense practical value to both private and public landowners.

\section{One of the major activities} in the field of timber management has been the development of growth and yield tables, both for natural stands and managed plantations. The initial set of yield tables in Miscellaneous Publication 50 (1929) was supplemented by Schumacher and Coile's 1960 publication "Growth and Yield of Natural Stands of the Southern Pines" and by a subsequent work describing soil-site relationships and yields of slash and loblolly pines (Coile and Schumacher 1964). The comprehensive information on growth and yields developed by researchers has been summarized in an annotated bibliography (Williston 1975) and in general reviews by Farrar (1979) and Burkhart (1979).

Many scientists have contributed to this wealth of knowledge. J.L. Clutter and associates at the University of Georgia (1984), in cooperation with Forest Service scientists, developed data on stand structure and yields of loblolly pine plantations in the lower coastal plain of the Southeast. Growth and yield data for loblolly and shortleaf pine in the west gulf coastal plain were published by Burton (1980). Similar findings have been made available for essentially all major forest types and conditions in the South.

In this research on timber yields, cooperation with forest industry groups and universities has been an important factor, as in the case of a plantation management research cooperative at the University of Georgia and cooperative slash pine density studies at Cordele, GA. The growth and yield data thus developed have proved to be essential for analyses of thinning and other management alternatives and for evaluation of attainable yields.

Research and experience in timber harvesting have led most large landowners in the southern pine region to opt for clearcutting and planting or seeding of pine stands. These practices have proved to be most 
compatible with use of fire and machines to control competing vegetation. Comprehensive guides for such management have been issued by the Georgia Forest Research Council (Wahlenberg 1965) and by Langdon and Bennett (1976), among others.

Research has also shown that for landowners wishing to retain a natural forest, or avoid the costs of site preparation and planting, forests can be managed on a selection system. The shelterwood system also has proved to be a low-cost and reliable system in the case of longleaf and shortleaf pine (e.g., Lawson 1979).

In essentially all pine management programs, control of hardwoods and other undesirable vegetation is essential for satisfactory regeneration, survival, and growth of the preferred pines. This fact is, of course, a major argument for prescribed burning. Early studies indicated that hardwoods could also be controlled by injecting unwanted trees with chemicals such as sodium arsenate. Subsequently, sprays of
2,4,5-T, picloram, and glyphosate were found to be effective (e.g., Peevy 1976). More recent studies showed promise for forestry applications of newer herbicides (Mann and Hayes 1978). Also worthy of note is a lengthy Agriculture Handbook called "Pesticide Background Statements," prepared by the Mitre Corporation (USDA Forest Service 1984b). The detailed data contained therein are essential in the preparation of environmental impact statements for projects involving the application of herbicides.

Use of herbicides has saved landowners millions of dollars in site preparation and timber-stand improvement and greatly increased growth of the more valuable pines. Intensified concern over environmental impacts from use of herbicides, however, and regulatory restrictions make future use of such chemical controls somewhat uncertain and suggest the need for continuing improvements in technology.

Research in use of fertilizers has demonstrated that 
significant increases in timber yields often can be achieved by application of nitrogen, phosphorus, potassium, or trace elements, and that yields of forage for livestock and wildlife can be similarly enhanced. Related research on use of sewage sludge for fertilization of forests showed this to be effective in increasing growth of loblolly and Virginia pines on depleted soils such as mine banks (e.g., Berry and Marx 1977). Criteria have been developed, as in the case of slash pine, for evaluating potential responses from use of different fertilizers, along with recommendations for rates and timing of applications (Stone 1983, p. 86).

Nutrient cycling has likewise received considerable attention from forest scientists. This has been due in part to increased interest in making use of forest biomass for energy as well as conventional logs and boltwood, with consequent questions of nutrient depletion (e.g., Wells 1977). Studies have shown, for example, that normal harvesting of tree boles results in nutrient losses that approximate nutrient inputs; but with harvesting on very short rotations and total use of biomass, nutrient losses may exceed the natural supply. Better understanding of the physical and chemical properties of forest soils also has resulted from the work of scientists such as W.F. Miller at Mississippi State University (1976).

The profitability of forest fertilization has been a matter of much uncertainty, in large part because of wide variations in forest conditions and responses to fertilization. Nevertheless, studies of slash pine stands in the Southeast (e.g., Fight and Dutrow 1981) have indicated that proper application of fertilizers at the right time could yield returns as high as 27 percent on investments in this practice.

Hardwood management has also been of much significance in the South. Hardwood types cover more than half the forest area of the region, including bottomlands with many valuable species and highproducing sites. The upland 
hardwoods, which so often compete with pines, also produce useful timber products as well as food and habitat for wildlife, and recreation opportunities. Logging practices in southern hardwood forests have generally involved the removal of only the higher quality trees, thus greatly reducing the quality and productivity of residual stands. Cutting also has often favored development of undesirable shadetolerant species, which now dominate many highly productive hardwood sites.

The research and demonstration efforts of J.A. Putman, L.C. Maisenhelder, J.S. McKnight, and coworkers provided valuable guidelines for the regeneration and culture of important bottomland hardwoods in both natural stands and in plantations (e.g., Putnam 1951). Studies of cutting methods in bottomland forests have pointed to clearcutting as the best practice if the objective is timber production (e.g., Johnson 1970). A summary of information on hardwood silviculture indicates that optimum species mix, high growth rates, and desirable tree form occur in full sunlight, with reproduction from advance growth, sprouts, and new seedlings (Prewitt 1982). Thinning stands helps concentrate growth on selected trees and permits some control of species composition, but even-aged management without thinning has been shown to offer advantages in avoidance of soil damage, epicormic branching, and damage to crop trees. Much information on the silviculture of upland hardwoods also has been developed through studies in Texas (e.g., Walker 1972) and elsewhere (USDA Forest Service 1980a).

Plantations of cottonwood, sycamore, and yellow poplar have shown much promise in many areas. Researchers have provided valuable information on effects of site and spacing on tree growth, as well as the importance of fertilization, use of cover crops and summer fallow, protection against insects and diseases, cultivation to ensure effective weed control, and use of genetically suitable stock (e.g., Maisenhelder 
1960). Although the total area of hardwood plantations is still limited, in 1979 some 16 companies were reported as having hardwood planting programs, mainly for cottonwoods (Prewitt 1982). Studies have also revealed potentials for growing eucalypts in Florida for use in pulp and paper and possibly other products (Geary and others 1983).

\section{Extensive cooperation} between researchers and industrial and other groups concerned with the management of southern hardwoods has been an important factor in southern forestry research. A southern hardwood forestry group, for example, organized in 1951, held regular field meetings to study hardwood management, sponsored classes in log and lumber grading, established long-term timber growth studies, and assisted in other research programs. A hardwood research cooperative in North Carolina involved industry and university participants in a series of growth and yield studies.
In the area of forest mensuration and biometrics, recruitment of Roy Chapman in the early 1930's added the first in a series of specialists who have contributed statistical expertise to a wide variety of research investigations. In later years other scientists, including J.G. Osborne, C.A. Bickford, T.C. Evans, Frank Freese, and H.T. Schreuder, provided similar assistance to improve sampling design and other statistical techniques in many research projects. L.R. Grosenbaugh led in the development of procedures for variable radius plot sampling and other techniques that helped increase efficiency in timber inventories and management planning (Grosenbaugh 1958). Cooperative efforts with F.X. Schumacher, of Duke University, included publication of an early text on sampling methods in forestry and range management (Schumacher and Chapman 1942). Scientists at the University of Alabama provided an understanding of relationships such as that between point density measurements and subse- 
quent timber growth (e.g., Johnson 1973).

The rapid expansion in availability and use of computers and computer specialists in recent decades greatly increased efficiency in many research projects. These have included timber inventories, predicting furture stand development with alternative management practices, estimating allowable cuts, and identifying optimum rotation ages for specified timber-management objectives.

\section{The information obtained} from the many studies conducted by forest scientists on the various aspects of southern forest management has been brought together from time to time in major publications. Knowledge relating to longleaf pine was summarized by
W.G. Wahlenberg in 1946 in a lengthy monograph. In 1960, he published a similar comprehensive treatise on loblolly pine, covering its ecology, regeneration, protection, growth, and other aspects of management. This book was based on the author's personal experience plus reviews of nearly 1,500 articles by other researchers. The comprehensive "Silivicultural Systems for the Major Forest Types in the United States" has provided guidelines for management of all the important pine and hardwood types in the South (Burns 1983). Symposia and conferences for both practicing foresters and researchers have also provided summaries of new information for both pines and hardwoods, together with recommendations for management of various species (e.g., Barnett 1981). 


\section{Research in Forest Insects and Diseases}

As interest in forestry spread across the South, it soon became evident that insects and diseases seriously limit yields of timber and cause major losses of structures built of wood. Cone and seed insects reduce seed production. Nursery diseases diminish output of quality planting stock. Tip moths, sawflies, webworms, weevils, bark beetles, rusts, root rots, canker rots, parasitic nematodes, and other pests take their toll of timber in established stands. Termites, wood borers, stains, and wood roots cause enormous losses in buildings and other structures.

An early example of successful research was the work of Ralph M. Lindgren, A.D. Chapman, and T.C. Scheffer in devising means of chemical control of sap stain in southern pine lumber. ${ }^{5}$ This was achieved

5 Much information on pathology research by Federal and university research scientists is contained in a "History of Forest Pathology Research in the South and Southeast" (Verrall 1982). through use of fungicidal dips, effective procedures for chemical application, and proper handling of wood during harvesting, milling, and seasoning (Scheffer and Lindgren 1940). Results of this work were of enormous economic importance to the southern pine lumber industry and to all owners and users of southern pine timber. Success in producing new knowledge of such great practical importance to the southern economy also brought recognition to the young Southern Forest Experiment Station and greatly strengthened support for the new field of forestry research (Wakeley 1964 unpubl.).

In many research efforts involving insects and disease, a logical and often time-consuming procedure was the initial step: learning the life history of forest pests and their relationships to the natural habitat.

Applied studies of chemical controls and integrated pest management subsequently added to the base of scientific knowledge and 
guidelines for forest protection. Such research has been supplemented by annual surveys of insect and disease conditions conducted cooperatively by administrative and research agencies (e.g., USDA Forest Service 1980b).

Among the many scientists making major contributions to knowledge of forest diseases was George Hepting, author of the 1971 volume "Diseases of Forest and Shade Trees," an important fundamental work for American forest pathologists. Scientists in the Bureau of Plant Industry and in the Forest Service after 1954 dominated forest disease research in the South for many years, but after 1960 universities began adding pathologists to their staffs. Many of these researchers transferred after long experience in Federal service, including J.S. Boyce, Jr., E.F. Jewell, E.P. Van Arsdell, E.R. Toole, and A.F. Verrall.

One of the more serious diseases in the South, the brownspot needle disease of longleaf pine, was the subject of early investiga- tions by H.H. Chapman, of Yale University, during the 1920's. His work, followed by the studies of Paul Siggers and other pathologists during the 1930's and 1940's, demonstrated methods of control through prescibed burning during the seedling stage of tree development (e.g., Siggers 1944). The fungicides Bordeaux mixture and benomyl were found to be effective in protecting planting stock in tree nurseries.

Fusiform rust, another highly destructive disease of southern pines, particularly slash and loblolly, also has been the subject of much research by both pathologists and geneticists. Careful selection of seed from more-resistant sources has been the principal way of dealing with this disease, and spraying with ferbam has helped provide control (Mexal and Snow 1978). Much of the accumulated knowledge of this disease has been summarized in proceedings of a symposium on management of fusiform rust in southern pines (Dinus and others 1977). 
A mysterious disease of loblolly and shortleaf pines, designated initially as "littleleaf disease," likewise has been of much concern to forest pathologists and forest managers. Studies by W.A. Campbell, O.L. Copeland, B. Zak, and coworkers led to the identification of a fungus, Phytophthora cinnamomi, as the causal factor (e.g., Campbell and Copeland 1954). The symptoms of littleleaf disease proved to be an expression of nitrogen starvation resulting from the killing of feeder roots by this fungus in heavy soils with poor drainage and aeration. Management guidelines developed from this research included directions for handling diseased plants, breeding for resistance, and favoring soil-building hardwoods.

Annosus root rot has been another cause of signicant mortality of southern pines, especially in thinned stands. Research by scientists such as R.C. Froelich, C.S. Hodges, E.G. Ruhlman, and E.W. Ross identified methods of preventing or reducing losses from this disease by silvicultural practices that include rating hazard by soil characteristics, summer thinning, and prescribed burning; selection of less susceptible species in planting programs; and direct control through application of borax on freshly cut stumps (e.g., Kuhlman and others 1976 and Froehlich and others 1977).

Among the numerous insect pests in southern forests, the southern pine beetle and the black turpentine beetle have been particularly destructive of standing trees. Major outbreaks of the southern pine beetle have occurred periodically, as in the late 1970's. An extensive program of research on this pest has been carried out in recent years, particularly through a Combined Forest Pest Research, Development, and Applications Program centered at Pineville, LA. This program combined the efforts of Federal, university, industry, and other organizations both in cooperative studies and in test applications of findings on an operational scale. In the search for effective controls, much information has been 
acquired and summarized in technical publications and symposium proceedings (e.g., Coster and Searcy 1979, Hastings and Coster 1981, Thatcher and others 1980, and USDA 1981).

Researchers have also developed hazard-rating systems that relate forest stand conditions to potential beetle infestation and appropriate control measures (Belanger and others 1981). Numerous insecticides such as chlorpyrifos have been identified and tested. Possible use of predators, such as the clerid beetles, has been studied, along with pheromones and other chemical attractants and inhibitors. Basic studies have evaluated enzyme-, protein-, and hormonerelated factors in pine beetle population growth. Still other experiments have determined the effects of cultural practices such as thinnings to favor more resistant tree species. Systems for modeling pine beetle population have also been developed (Stephen and others 1980). Through such investigations, a number of recommendations have been developed that may prevent or reduce outbreaks of the southern pine beetle (Swaine and Remion 1981).

Research on the black turpentine beetle revealed that infestations in thinned loblolly pine plantations, for example, can be limited by minimizing injury to residual trees, avoiding harvesting on waterlogged soils, and applying lindane to damaged or infected trees (Feduccia and Mann 1976). Damage from cone and seed insects in seed orchards can be limited through use of carbofuran (e.g., DeBarr 1978). The pales weevil, a pest causing high losses on some recently cutover and planted pine lands, can be suppressed by chlorpyrifos and other insecticides (Nord and others 1978). Tests of the a microbial insecticide $\mathrm{Ba}$ cillus thuringiensis, have shown much promise in 
protecting trees from defoliation. 6

Much research also has been conducted on ways of protecting wood products from subterranean termites and other wood-destroying insects and fungi. In the late 1930's, T.E. Snyder initiated work on termites, and M.B. Christian sought ways of controlling powderpost beetles in hardwood lumber. Starting in the 1940's, H.R. Johnson and coworkers identified pesticides and procedures for protecting wood in houses

6 The great variety and importance of forest insect pests have been described in "Eastern Forest Insects" by Whiteford Baker (1972). In 1985 the Forest Service published an update of this book, "Insects of Eastern Forests," Miscellaneous Publication 1426. and other structures from attack by termites and other insects. Related research developed ways of protecting wood structures from decay associated with rain seepage and condensation in air-cooled buildings by use of nonpressure preservative treatment (Verrall 1982).

Results of these studies, together with work on wood preservatives at such locations as the Forest Products Laboratory at Madison, WI, and Mississippi State University, have benefited consumers through greatly improved performance of wood in many uses. Federal Housing Administration standards, for example, and military manuals for prevention of insect and disease attack in structures are based on findings of this research. 
Another early venture of the southern forest experiment stations was a regional survey of timber resources, conducted under authorizations in the McSweeney McNary Forest Research Act of 1928. The southern forest survey was part of a nationwide effort designed to provide an inventory and appraisal of both current and prospective timber resources and timber requirements in the United States, an essential basis for evaluating the timber situation and outlook.

The forest survey represented, in effect, a major intensification of forest resource analyses contained in series of national publications dating back to the period 1878-82, when Franklin B. Hough issued a surprisingly comprehensive "Report Upon Forestry." This was followed by other timber resource reports, notably a Bureau of Corporations Report of 1911 and the Copeland Report of 1933 , as well as more recent timber resource studies, including Timber Reviews of 1952 and 1970 and culminating in "An Analysis of the Timber Situation in the United States, 1952-2030" (USDA Forest Service 1982a). The earlier resource studies contained generalized and necessarily limited information on timber resources. The more recent national reports have included considerable data by States and increasing detail on the changing forest situation.

Some early reports on forest and range resources were issued in the South, as in the case of the Bureau of Economic and Business Research in Florida, which published studies dealing with timber resources and industries and the naval stores industry in that State (Campbell and McCracken 1932). In the 1930's and 1940's, the Florida Agricultural Experiment Station also issued reports on forest pastures and conditions of vegetation on rural lands.

In 1931, the southern forest survey staff, under the leadership of G.H. Lentz, followed by Inman ("Cap") Eldridge, undertook the major task of obtaining detailed information on forest areas throughout the 
South: the volume, size, and ownership of the timber resources thereon, and the growth, mortality, and utilization of timber. Information on the gum naval stores industry also was included in recognition of the significance in earlier years of that southern forest-based industry.

Survey reports issued in the 1930's soon revealed a surprising recovery of southern pine forests, despite the extensive logging and widespread fires characteristic throughout the South. Improving forest conditions reflected better control of wildfires and the natural ability of southern pines to restock cutover and burned areas. Natural seeding of abandoned croplands during the 1920's, the depression years of the 1930's, and the period after World War II also was of considerable importance. Establishment of pine plantations by the Civilian Conservation Corps in the 1930's and by many industrial and other landowners after World War II also added to the pine timber resource base.
The survey reports that came from the printers beginning in 1934 were of special interest to the pulp and paper industry, then on the threshold of a spectacular expansion throughout the South. Information on the increasing availability of pine pulpwood supplies undoubtedly helped stimulate construction of more and larger mills, even in the depressed years of the 1930's. Pulping capacity at southern pulp mills, amounting to about 3,000 tons per day in 1930, nearly quadrupled by 1940 , while the number of mills rose about 25 percent (from 40 to 49) in this period. Continued expansion in the years after World War II raised pulping capacity in the South to some 110,000 tons per day by 1979 , or about 65 percent of the Nation's total pulping capacity.

The 1960's and 1970's also saw the rapid development of a major southern pine plywood industry, as well as marked resurgence of the southern pine lumber industry, all guided in part by resource data from the forest survey. Increasingly 
detailed resource data also helped guide investments in acquisition of timberlands and forest management to support long-range industrial expansion.

By the early 1940's, the southern forest survey had covered most of the South with a grid of lines and plots established by field crews who traveled on foot through thousands of miles of forested areas, swamps, coastal plains, and mountains. The timber inventory information collected in this field work was summarized in some 53 reports, which provided the first set of comprehensive and statistically valid data on the varied timber resources of the South. Prominent among the analysts and authors of these reports in this prewar era were A.R. Spillers, S.B. Hutchinson, R.K. Winters, and F.A. Ineson.

In 1946, after the return of personnel from wartime duties and increases in apropriations, resurvey of southern forests was begun, followed by subsequent resurveys at approximately 10-year intervals. These more recent resource inven- tories utilized new techniques involving land classification through interpretation of aerial photographs, measurements of timber on preselected variable-radius field plots, and use of computers for rapid and detailed compilations of resource data.

Many members of the Forest Service and cooperating agencies made significant contributions in this work under such survey leaders as P.A. Wheeler, J.F. Christopher, J.W. Cruikshank, J.F. McCormack, and J. McClure. More than 40 other authors also prepared publications on timber resources, industrial use of timber products, trends in timber growth, and related information.

Other specialists is statistics and biometry helped develop improved methodology that materially improved the efficiency and usefulness of the forest survey. These improvements related to sampling methods, use of variable plots, and better methods of projecting timber growth and inventories under different manage- 
ment alternatives (e.g.,

Larson and Goforth 1974).

C. Mesavage and J.W. Girard (1946) developed volume tables for estimating the board foot and cubic foot contents of standing timber. Many other permanent and temporary survey staff members contributed by interpreting aerial photos, measuring field plots, compiling inventory growth and utilization data, and publishing reports.

\section{Cooperators in State} forestry agencies and in forest industries likewise made very substantial contributions of money, field crews, or other assistance to speed up and intensify the survey program. The major study entitled "The South's Third Forest" (Southern Forest Resource Analysis Committee 1969), prepared by P.A. Wheeler under industry sponsorship, also illustrated the value of survey data for evaluation and development of forestry programs. This analysis traced the development of forestry practices in the South and identified measures needed to assure adequate timber supplies for the expanding wood industries in the region.

During the Korean War of the early 1950's, special analyses of timber resource data for different parts of the South helped determine the adequacy of timber supplies for new industrial plant capacity, particularly for expanded pulp and paper production. Other surveys of equipment requirements of the forest industries provided essential data for defense planning. Also in the 1950's, cooperative surveys with the Forest Products Laboratory provided information on the range in specific gravity of wood in southern pine trees. Subsequently, inventories to determine weights and volumes of both timber and other vegetation furnished a measure of the potential availability of biomass for energy production.

Significant progress also has been made in broadening surveys to encompass nontimber resources and uses (USDA Forest Service 1978b). As early as 1959, studies were undertaken to obtain data on range owner- 
ship and utilization in surveys of the Arkansas Ozarks. In the early 1960's, procedures for incorporating evaluations of deer habitat were tested in a resurvey of north Georgia. A cooperative survey of timber and range resources in Louisiana in 1973 included evaluations of forage availability and use, fire history, and range condition. And in 1977, the Southeastern Station broadened its timber inventory work in South Carolina to obtain data on wildlife habitat, range, water, soils, understory vegetation, and recreation.
Information provided by the forest survey on the timber situation and outlook in each State has provided a measure of the effectiveness of Federal, State, and private forestry programs, together with an indication of opportunities for changes in these programs. Such use of forest resource data is illustrated in individual State reports and programs, and in periodic national assessments and programs called for by the Forest and Rangeland Renewable Resources Act of 1974 . 
Closely related to surveys and analyses of forest resources have been a number of studies of forest land ownership, conducted over the past several decades by Forest Service researchers such as L.M. James, A.S. Todd, A. Pleasanton, and W.C. Anderson; by scientists in southern universities, such as C.B. Marlin (1978) in Louisiana; and by the American Forestry Association in North Carolina (Pomeroy and Yoho 1964). These studies have provided key information on such matters as owner characteristics, extent of landholdings, problems encountered in management of private forest lands, and landowner responses to forestry assistance programs. Generally these have shown a preponderance of small forest ownerships held by a wide variety of owners who, for various reasons, have been unwilling or unable to invest capital in planting or other timber-growing measures (e.g., Birch and others 1982).

A number of studies have shown, nevertheless, that cultural measures to produce southern pines could be undertaken in many areas at moderate costs and with significant returns on investments. In the Southeastern United States, for example, analysis suggests that over 100 million acres of forest land would qualify for some management treatment, with investment returns ranging from 3 to 16 percent (Dutrow 1978). Conversion of oakpine types to pine plantations, for example, has been identified as a principal way of increasing pine timber supplies on millions of acres of southern forests. Guides have been prepared to aid investors contemplating such action (e.g., Anderson and Guttenberg 1971).

In recognition of the large importance of nonindustrial ownersips in the timber supply picture, and evidence of promising investment opportunities, a number of public programs have been adopted to assist owners in improving the management of their forests. In addition to Federal technical assistance and cost sharing, several South- 
ern States have established incentive programs funded by severance taxes or by funding from the forest industries, as in Texas. Many private firms have also developed "tree farm family" programs or related efforts to work with other landowners in increasing timber production.

An evaluation of the Federal Forestry Incentives Program, conducted by representatives of the Forest Service, the University of Minnesota, the USDA's Agricultural Stabilization and Conservation Service, and several State forestry agencies, have indicated that this assistance program has been a cost-effective way to increase timber yields on nonindustrial forests (Risbrudt and Ellefson 1983). Investments in such measures as site preparation and planting, precommercoial thinning, and cull tree removal were estimated to yield more than an 8-percent real rate of return while producing significant increases in future yields of timber. In addition, soil and water conservation, wildlife habitat, recreation, and esthetics were enhanced in varying degree.

Economic aspects of forest management in both pine and hardwood types have been given considerable attention by researchers in the South. In the 1930's, W.E. Bond and associates issued the first in a series of reports on the costs and returns of sustained-yield forestry in southern pine types (Bond and others 1937). W.A. Duerr and S. Guttenberg developed guidelines for determining the financial maturity of timber (e.g., Duerr and others 1956). Various analyses of economic aspects of timber management, fire control, or other phases of forestry also have been conducted as part of broader silvicultural investigations.

Application of operations research techniques to sawmill operations demonstrated how profits might be maximized by changing production or marketing factors (Row and others 1965). Methods of computer analysis were also developed for logging operations to help estimate the most profitable timber-harvesting 
procedures (Koger and Webster 1984).

Among other studies of forest policy issues was the monumental work of the forest taxation inquiry, designed to find general solutions to problems of forest property taxation (Fairchild 1935). Subsequent studies of forest taxation more specifically oriented to the South included the work of such scientists as R.R. Craig and W.C. Siegel at the Southern Forest Experiment Station, Leon Hargreaves, Jr., at the Georgia Forestry Commission, and W.O. Klemperer at the Virginia Polytechnic Institute. Legislators and others have used such studies in evaluating possible impacts of various tax policies on forest ownership and forestry practices.

The marketing of southern pine and hardwood products has likewise been a subject for research by many scientists. For more than a century, periodic surveys of production, prices, and end uses of foresty products have been conducted by the U.S. Bureau of the Census, the Forest Service, and various State agencies. Beginning in the 1950's, such researchers as H.E. Dickerhoof, C.A. Fasick, W.C. Anderson, and D.L. Holley, Jr., conducted local marketing studies on consumer attitudes toward use of wood and competing products and related factors affecting consumption of southern wood products. Studies of pulpwooding revealed the production and marketing structure of this important southern industry (e.g., Rawlins and Sorensen 1968). Both Federal and State agencies have issued series of local price and market reports for stumpage, logs, and pulpwood of southern timber species. 


\section{Research in Timber Utilization}

The research and development efforts of both public and industrial research organizations in the South have led to many improvements in logging, manufacture of wood products, and use of wood materials for construction and other purposes.

Investigations dealing with properties and uses of the southern pines began as early as 1882 in the Division of Forestry in the U.S. Department of Agriculture, although funds and trained personnel were, of course, extremely limited. Such work led to the discovery that lumber from longleaf pine trees tapped for naval stores was as strong as that from untapped timber; therefore, much of the prevailing waste of tapped trees was unnecessary. Other studies showed that seasoning lumber enhanced its strength. Research around the turn of the century on preservative treatment of railway ties and other wood products similarly helped point the way to better use and conservation of timber resources.

The Forest Products Laboratory of the USDA Forest Service, established in 1910 at Madison, WI, in cooperation with the University of Wisconsin, soon became a major center of knowledge leading to more rational and less wasteful use of timber. Because of their relative abundance and usefulness, the southern pines became the subject of much of the research at this world famous laboratory. In 1910, there were no highly efficient sawmills or dry kilns; pulp and paper production was limited and primitive; hardwoods were seldom used for paper; there were no plywoods, particleboards, or laminated timbers; and wood preservation was of limited application. ${ }^{7}$

\footnotetext{
7 "History of the U.S. Forest Products Laboratory, 1920-1963," by Charles H. Nelson (1971), provides a detailed description of the extensive research conducted at this institution. Research performed in subsequent years has been described in annual reports of the laboratory.
} 
The early timber testing work of the Bureau of Forestry and several university laboratories was soon materially expanded at the Madison laboratory to include strength tests of various sizes and grades of most commercial timbers and effects of factors such as defect and moisture content. As early as 1915, the Southern Pine Association and the American Society of Testing Materials adopted lumber-grading rules prepared at the Madison laboratory. These and subsequently developed standards for plywood and other products have provided architects and engineers with accurate data for design of structures, reliable data for commercial specifications, and a basis for substitution for scarce species or materials.

Another major highlight of utilization research at the Forest Products Laboratory was the development and patenting of an efficient dry kiln by H.D. Tieman. This highly practical development was the result of years of intensive research on the fundamental principles of drying, shrinkage, and effects of moisture content in wood of various species. The laboratory at Madison also sponsored courses in kiln drying to disseminate knowledge of modern drying methods. These efforts have helped reduce use of green lumber in construction, with consequent improvement in performance and consumer benefits.

Research aimed at improving the efficiency of sawmills led to better equipment and plant layout and more productive cutting practices. Thus lumber yields, particularly from small logs, can be substantially increased through computer-based selection of the "best opening face" of each log-a discovery of special significance in view of the increasing proportion of small logs in the available timber supply.

In the area of pulp and paper research, early work by industrial researchers and by scientists at the Madison laboratory and other institutions pointed the way to successful production of kraft pulps from southern pines, and the ensuing enormous 
expansion of the southern kraft pulp and paper industry. With rapid growth in demand for kraft pulps, papers, and board, the discovery that southern pines were suitable for these products was of great importance. C.F. Herty and others also found that it was feasible to make newsprint from the southern pines. At the Madison laboratory, scientists such as C.E. Currens and G.H.

Chidester found that strong white pulps could be made from southern pines through a modified kraft process in combination with two-stage bleaching.

Development of the semichemical pulping process at Madison also ranked as a major accomplishment. This process, involving a combination of chemical and mechanical pulping, provided an efficient method for pulping hitherto unusable southern hardwoods and proved to be particularly suitable for production of the corrugating medium used in container board. Related studies also led to development of a high-yield "cold soda" process for pulping hardwoods. And a new process for "press drying" paper, using both heat and pressure simultaneously, yielded highstrength papers from hardwoods while saving on energy otherwise usable for drying. The basic work of such men as C.W. McMillin (1978) helped in such developments through better understanding of wood chemistry, fiber characteristics, and relations of such factors to properties of wood pulps, paper, and fiberboards.

Wartime activities at the Madison laboratory in the 1940's included the development and testing of packing boxes and other containers for military use. Improved designs and specifications for shipping different commodities in lumber, veener, plywood, and container board resulted in large reductions in breakage and financial savings in both military and civilian uses. Development of pallets for movement and storage of goods was likewise of great importance to the military, as well as to many peacetime users. 
Building on the wartime experience in providing technical services to the forest industries, a "Forest Utilization Service" was established at the various experiment stations of the Forest Service. This program provided a means of stimulating research at utilization laboratories and a way of getting results of research into practice with minimum delays. In the South, men such as M.M. Lehrbas, C.R. Lockard, R.D. Carpenter, R.H. Page, and W.R. Smith provided such liaison between the Madison laboratory and the forest industries. They provided a wealth of information to timber producers on such matters as lumber seasoning, milling, wood preservation, gluing of wood products, pulp chip procurement and storage, and log and lumber grading. Some years later, similar assistance was provided by extension specialists at some of the southern universities.

In the early postwar years, investigations were undertaken to develop log and tree grades for southern pines, supplementing grades for hardwoods developed in earlier years. These provided a means of improving efficiency in logging and milling and making more accurate appraisals of timber values. The work of C.R. Lockard, R.D. Carpenter, R.A. Campbell, L.M. James, J.A. Putnam, and others provided effective log grading rules both for southern pines and for hardwoods (e.g., Lockard and others 1950).

The 1960's also saw the development of technology that permitted efficient manufacture of plywood from the southern pines. This resulted from coooperative efforts of the plywood industry and Forest Products Laboratory researchers, who provided technical information on wood characteristics, adhesives, machining techniques, and criteria for commercial standards. The expansion of this new southern pine plywood industry has been spectacular, with production in 1982 reaching more than half the total U.S. output of structural panels. During the 1960's, use of sawmill residues for 
pulp chips also expanded rapidly, thanks in large part to experiments by the pulp and paper industry.

Another postwar development in utilization research was the establishment or expansion of forest products laboratories in a number of Southern States. These included a laboratory at North Carolina State University, well known for research on pulp and paper. A laboratory at Mississippi State University developed special expertise in wood preservation. Universities in Georgia, Alabama, Virginia, and Texas also built up forest products laboratories. The Forest Service established two regional laboratories in the South in the 1960's, one at Alexandria, $L A$, initially under the direction of Peter Koch, and one at Athens, GA, under R.R. Bloomquist.

Research conducted at Federal, State, and industrial laboratories has led to many new products or uses as well as greatly improved efficiency in the manufacture of conventional wood-based materials. Research on housing sys- tems, for example, has helped reduce costs and improve performance of both conventional and factory-built housing. New markets have been developed for preservativetreated wood foundations. Construction techniques using improved vapor barriers have provided practicable and economical methods of moisture control.

Other developments in use of wood include glued laminated arches, beams, and other items made of southern pine as well as other superior species. Development of these engineered products stemmed in large part from the work of many researchers in design, adhesives, finger jointing, timber connectors, wood preservatives, and finishing.

Research at Madison and other laboratories also led to the development and commercial manufacture of a variety of panel products (e.g., USDA Forest Service 1978c). These include fiberboard, particleboard, flakeboard, oriented strand board, honeycomb panels, composite framing, panels 
composed of a particleboard core between layers of veneer, and other sandwich materials of wood with metal or plastic. New products such as resin-treated papers and densified products called "compreg" and "impreg" also have been produced and have proved important for military and other purposes.

Early work on wood preservation was soon expanded at the Madison laboratory and at other institutions such as Mississippi State to include fundmental studies of chemical, physical, and toxic qualities of various preservatives, and ways of improving preservatives and treating processes. Greater efficiency in the wood-preserving industry and ways of adjusting to environmental regulations have been important benefits of this research. Related studies of the flammability of different woods treated with fire-retardant chemicals also helped improve woodtreating processes. Research on paints and painting methods has provided knowledge that resulted in better performance of wood in construc- tion and savings in timber resources and consumer dollars.

Engineering research and development relating to logging and manufacture of wood products likewise produced much new technology and improved equipment. For example, a cooperative project involving the Georgia Pacific Company, Auburn University, and equipment manufacturers led to development of machines for chipping trees in the woods. Other companies, such as International Paper, working with equipment manufacturers did much to develop pulpwood and tree harvesters.

The information developed through such utilization research has heen issued in many publications, including a major work by Peter Koch on utilization of the southern pines (1972). In 1978 a symposium on complete tree utilization of southern pines also provided much useful information on the latest developments in various aspects of southern pine timber utilization (McMillin 1978). 
Research dealing with the naval stores industry involving the tapping of longleaf and slash pines for oleoresin was launched at a relatively early date. Work by Charles F. Herty in 1903 resulted in improved methods of tapping trees using cups and gutters rather than the highly destructive system of chopping a box in the base of tapped trees. In the early 1920's, Lenthall Wayman, workinn in Starke, FL, developend more efficient methods of chipping trees. In the 1930's, a number of other members of the southern forest experiment stations joined the Florida project in naval stores, including V.L. Harper, T.A. Liefeld, L.E. House, and C.H. Coulter. A series of reports dealing with resin production resulted from this work, including a major handbook (USDA Forest Service 1935).

After 1940, work on chemical stimulation of gum yields included the discovery that gum flows could be greatly increased by treating the faces of tapped trees with a sulphuric acid pasteresulting in yields up to 150 percent greater than from untreated trees (Stubbs and others 1984). Development of plastic cups and gutters for gum collection improved the quality of gum. And new equipment such as rossing tools helped lower costs and improve working conditions. It was also determined in more recent years that application of the herbicide paraquat to wounds on southern pines causes wood to be soaked with resin that can be recovered during the pulping process. Such treatments yielded increases of more than 150 percent in extractives from slash and longleaf pines (Drew and Roberts 1978). Related studies of insect attacks on tapped trees revealed that spraying with lindane would limit mortality that often followed chipping (Merkel and Clark 1981). Cooperative work on this significant development was carried out for a period through a lightwood research coordinating committee (Esser 1979). 


\section{Research on Use of Forest Land by Livestock}

The long-established practice of grazing cattle and hogs on the "open range" of the South, with woodsburning the primary tool of management, posed many questions for researchers at forestry and agricultural experiment stations in the region. Could grazing be made compatible with timber production? Would both timber growing and livestock production be profitable on forest lands?

An impressive series of investigations dealing with the grazing of cattle on forest ranges, particularly on the coastal plain, was begun in the 1940's by scientists such as H.H. Biswell, R.S. Campbell, J.T. Cassidy, L.K. Halls, R.A. Read, and B.L. Southwell. Both studies and observations indicated that in the longleaf-slash pine belt, properly managed cattle grazing does little harm to pine regeneration and growth and utilizes grass and other forage that might otherwise feed wildfires (e.g., Campbell and Cassidy 1951).
Studies of prescribed burning demonstrated that controlled fires improve the nutrient content and digestibility of forage and increase its availability for livestock (e.g., Duvall and Whitaker 1964). Related studies revealed how open strips of improved pasture can serve as firebreaks, as well as provide feed and access to adjoining forest range (Halls and others 1960).

Supplemental feeding and access to improved pastures proved to be important elements in efficient systems of cattle management that utilize forest ranges (Duncan and Epps 1958). Forage on forest areas was found to be generally deficient in energy and nutrients required for good animal growth, especially for breeding herds. Hence crude protein, phosphorus, and trace elements often must be supplied for efficient livestock production (Lewis 1983). In other studies seasonal use proved to be preferable to year-round forest grazing. Proper stocking of both trees and livestock was likewise shown 
to be essential for a desirable balance of the combination of timber and cattle. Economic evaluations of cattle-management systems indicated that with good management, herd control, and supplemental feeding, cattle grazing on longleaf pine forest ranges can yield acceptable returns on the necessary investments (e.g., Halls and Duvall 1961).

The grazing of hogs in longleaf pine forests, with consequent destruction of seedlings, has been a matter of conflict since foresters came to the South. Studies by W. Hopkins (1951) and others confirmed the need to exclude the piney woods pigs if new forests of longleaf pine were to survive. Firms such as the Great Southern Lumber Company and the Urania Lumber Company had long fenced their holdings, but the regional custom of allowing hogs to roam free and graze anywhere was persistent. It was not until the mid-1950's that southern legislatures passed effective laws controlling the free ranging of the half-wild razorback hogs.

Information on management of livestock on forest ranges has been made available through many publications (e.g., Burd and others 1984), as well as through symposia on specific forest types such as the slash pine ecosystem (Lewis 1983). Many studies by agricultural experiment stations and universities have added to knowledge of basic ecological relationships relevant for both tree growing and management of forest ranges and livestock. ${ }^{8}$

\footnotetext{
8 The substantial amount of research on range management conducted in the South in recent years is evidenced by a bibliography that shows more than a thousand entries for only the 6-year period 1973-78. This bibliography was a project of the Committee on Renewable Resources and is available for searching through the Bibliographic Retrieval Service, Inc., with access through the technology transfer group of the USDA Forest Service in Washington, DC.
} 


\section{Research in Wildlife Habitat Management}

Ways of enhancing production of wildlife by improvements in forest habitats have been studied by many researchers in the South. The grazing of cattle on forest ranges, for example, was found to produce variable impacts on wildlife as well as on timber production (e.g., Pearson 1980). Moore and Terry (1981) found that continuous year-round grazing on southeastern pine lands often degrades both wildlife habitat and range conditions, whereas short periods of grazing followed by rest periods tend to improve wildlife habitat.

The classic early work of H.L. Stoddard (1931) dealing with management of quail outlined methods for enhancing habitat of this important game species. Strong interest in whitetailed deer in the South also stimulated considerable research on this species by scientists such as R.A. Read, L.K. Halls, H.L. Short, J.R. Stransky, and T.H.

Ripley. A symposium on deer, convened in Nacogdoches, TX, in 1969, consolidated known information and proposed guides for improving deer habitat and production in forest areas (Halls 1969).

Other research included evaluations of forage availability and digestibility and the physiology and nutrition of deer (e.g., Halls and Boyd 1982). Related studies explored relationships between deer management and habitat and silvicultural practices. These revealed substantial changes in yields of forage with timberstand development and emphasized the need for maintaining a productive understory by periodic thinnings and prescribed burnings.

Cooperative work with State game agencies has often been of major significance in wildlife management research, as in the case of studies with the Louisiana Wildlife and Fish Commission dealing with deer potentials in selectively cut pine-hardwood stands (Blair and Brunett 1977). Much additional research also has been conducted by the U.S. Fish and Wildlife Service and by State game 
commissions, particularly on production and management of quail, deer, and turkey. These studies have been financed in considerable part by "PittmanRobertson funds" derived from Federal excise taxes on sales of arms and ammunition.

With the emphasis on environmental considerations in recent years, managers of public lands such as national forests have also given increasing attention to management programs that recognize nongame wildlife habitat requirements. The Southeastern Forest Experiment Station and Clemson University, for example, have provided comprehensive descriptions of bird-habitat relationships for some 234 bird species found in southern forests (Hamel and others 1982). Studies of endangered species such as the red-cockaded woodpecker have been undertaken to determine possible means of sustaining remaining populations (Hooper and others 1980).

These investigations of wildlife communities and habitat requirements have shown the need for a diversity of tree species, stand ages and habitat, and retention of snags and cavity trees for some species. It is apparent that such measures directly affect timber rotation ages, silvicultural methods, and timber-harvesting techniques. To forest managers on public lands at least, knowledge of such relationships has become essential for achieving an acceptable balance between timber and other nontimber uses, such as wildlife, grazing, and recreation.

Recreational uses of southern forests have long included hunting for deer, quail, and squirrels as part of the culture of the rural South. This has often led to sharp conflicts with modern timber-growing practices. In partial response, pulp and paper companies and other large landowners (including the Forest Service) have generally permitted public hunting and often manage their forest land to increase hunting opportunities. Some industrial and other large owners lease forest lands to selected hunting groups 
in the hope that incendiary fires and vandalism will thereby be reduced and some income realized.

Forest managers also have had to accommodate increasing numbers of campers, fishermen, and other recreational users of forest lands (Cordell 1979). Damage to property has usually been found to be the most important problem associated with these recreational uses of southern forests. 
Around 1930, the Southern Forest Experiment Station undertook a limited program of research on methods of controlling floods and soil erosion by establishing forest cover on eroding areas. These investigations were centered in northern Mississippi, where massive gully erosion and siltation of rich farmlands provided spectacular examples of damage to land and people. Under the leadership of H.G. Meginnis in association with W.M. Broadfoot, G.H. Lentz, and J.D. Sinclair, experimental work was begun with erosion and runoff plots and the planting of pine to maintain soil cover (Meginnis 1935).

This highly successful research, and later studies in the Piedmont area of the Carolinas, where soil erosion also was severe, plus related studies by the Soil Conservation Service and the Agricultural Research Service, have provided a sound technical basis for extensive planting and land management programs to control destructive erosion in forest areas. Related studies on soil moisture by
R. Zahner and D.C. McClurkin, for example, also helped explain relationships between soil water and timber growth.

\section{Growing concern over} protection of the environment, accompanied by such events as passage of the Water Pollution Control Act of 1972 and subsequent amendments, also led in the 1970's to expanded research on nonpoint pollution from forest areas. These investigations have included evaluations of the impacts of alternative forms of land management on municipal watersheds and effects of herbicides, pesticides, and fertilizers on water quality.

In pine flatwoods, for example, studies of timber harvesting showed negligible effects on movement of stream sediments, some temporary increases in water yields and peak flows, and significant removal of nutrients only with windrowing of residual material (Swindel and others 1983). Measures to control unwanted vegetation resulted in some increases in water yields and speed of runoff, 
with mechanical control techniques showing more impact than chemical or manual methods (Douglas 1981). Studies of chemical controls for vegetation revealed that some herbicides enter nearby streams even when crews follow recommendations for application.

Prescribed burning in areas containing ephemeral streams in the Piedmont of South Carolina showed no significant effects on stream runoff, sediment, or nutrient concentrations (Douglas and Van Lear 1983). Similar results were reported in coastal plain pine forests (Richter and others 1982). Tests of effects of normal silvicultural practices on nonpoint pollution conducted by J.D. Hewlett (1983) and associates at the University of Georgia showed no significant effects on water quality or soil fertility. Such research findings have been applied in the development of "best management practices" required by Federal and State water-quality legislation to assure acceptable standards of water quality.

Research at the Coweeta Hydrologic Laboratory in the mountains of North Carolina outside the southern pine region likewise added greatly to the fund of knowledge on general relationships between water and forest management. Experiments by C.R. Hursh and M.D. Hoover at this famous installation have shown effects of various treatments of hardwood vegetation on streamflows and soil movement. Results have been widely used in the management of both public and private forest watersheds. 


\section{Summary}

It is evident from this brief history that southern forests are used for many purposes, including production of timber, livestock, wildlife, recreational opportunities, and water. Most research investigations have related primarily to single or limited combinations of these uses, although some work has provided general concepts for integrating timber and related benefits (Boyce 1978).

The hundreds of research scientists working in the South in recent decades have produced thousands of publications that provide information on a wide spectrum of forestry activities from seed collection to ultimate use of forest products and services. Research findings have led to increases in timber production and greater efficiency in production and use of timber products; enhanced values of forest and range resources; and expanded employment, income, and nontimber uses throughout the South. The new knowledge and new technology produced by forestry scientists have unquestionably been of major and lasting benefit to the economy of the South and to the Nation as a whole. 
Anderson, Walter C.; Guttenberg,

Sam. 1971.

Investor's guide to converting southern oak-pine types. Res. Pap. SO-72. New Orleans, LA: U.S. Department of Agriculture, Forest Service, Southern Forest Experiment Station. $10 \mathrm{p}$.

\section{Bailey, Robert L.; Pienaar, Leon} V.; Shiver, Barry D.; Rheney, John W. 1982.

Stand structure and yield of site-prepared slash pine plantations. Res. Bull. 291. Athens, GA: University of Georgia, College of Agriculture. $83 \mathrm{p}$.

Baker, Whiteford. 1972.

Eastern forest insects. Misc. Publ. 1175. Washington, DC: U.S.

Department of Agriculture, Forest Service. $641 \mathrm{p}$.

Barnett, J.P., ed. 1981.

Proceedings, 1st biennial southern silvicultural research conference; 1980 November 6-7; Atlanta, GA. Gen. Tech. Rep. SO-34. New Orleans, LA: U.S. Department of Agriculture, Forest Service, Southern Forest Experiment Station. 375 p.

Barnett, J.P.; McGilvray, John M. 1981.

Container planting systems for the South. Res. Pap. SO-167. New Orleans, LA: U.S. Department of Agriculture, Forest Service, Southern Forest Experiment Station. $21 \mathrm{p}$.
Belanger, Roger P.; Porterfield, Richard L.; Rowell, Charles E. 1981.

Development and validation of systems for rating the susceptibility of natural stands in the Piedmont of Georgia to attack by the southern pine beetle. In: Hedden, Roy L.; Barras, Stanley J.; Coster, Jack E., tech. coords. Hazard-rating systems in forest insect pest management: symposium proceedings; 1980 July 31 -August 1; Athens, GA. Gen. Tech. Rep. WO-27. Washington, DC: U.S. Department of Agriculture, Forest Service: 79-86.

Berry, Charles R.; Marx, Donald H. 1977.

Growth of loblolly pine seedlings in strip mined kaolin spoil as influenced by sewage sludge. Journal of Environmental Quality. 6: $379-381$.

Bertrand, A.L.; Baird, A.W. 1975. Incendiarism in southern forests: a decade of sociological research. Bull. 838. Starkville, MS: Mississippi Agricultural Experiment Station. $40 \mathrm{p}$.

Bey, Calvin F.; Snyder, E. Bayne. 1978.

Genetic gains through testing and crossing longleaf pine plus trees. Res. Note SO-241. New Orleans, LA: U.S. Department of Agriculture, Forest Service, Southern Forest Experiment Station. $5 \mathrm{p}$. 
Birch, Thomas W.; Lewis, Douglas G.; Kaiser, H. Fred. 1982.

The private forest landowners of the United States. Res. Bull. WO-1. Washington, DC: U.S. Department of Agriculture, Forest Service and Economics Research Service. 64 p.

Blair, R.M.; Brunett, L.E. 1977. Deer habitat potential of pine hardwood forests in Louisiana. Res. Pap. SO-136. New Orleans, LA: U.S. Department of Agriculture, Forest Service, Southern Forest Experiment Station. $11 \mathrm{p}$.

Bond, W.E.; Wahlenberg, W.G.;

Kirkland, B.P. 1937.

Profitable management of shortleaf-loblolly pine for sustained yield. Gen. Pap. 70. New Orleans, LA: U.S. Department of Agriculture, Forest Service, Southern Forest Experiment Station. $37 \mathrm{p}$.

\section{Brender, E.V. 1973.}

Silviculture of loblolly pine in the Georgia Piedmont. Rep. 33. Macon, GA: Georgia Forest Research Council. 74 p.

\section{Burd, Nathan A.; Lewis, Clifford}

E.; Pearson, Henry A. 1984.

Management of southern pine forests for cattle production. Gen. Rep. R8-GR4. Atlanta, GA: U.S. Department of Agriculture, Forest Service, Southern Region. 22 p.
Burkhart, Harold E. 1979.

Growth and yield of the southern pines-states of the art. In: Southern Forest Economics Workshop; 1979 March 22; Chapel Hill, NC. Chapel Hill, NC: Duke University. $11 \mathrm{p}$.

Burns, Russell M., comp. 1983.

Silvicultural systems for the major forest types of the United States. Agric. Handb. 456. Washington, DC: U.S. Department of Agriculture, Forest Service. 191 p.

Burton, J.D. 1980.

Growth and yield in managed stands of loblolly and shortleaf pine in the west gulf coastal plain. Res. Pap. SO-159. New Orleans, LA: U.S. Department of Agriculture, Forest Service, Southern Forest Experiment Station. $23 \mathrm{p}$.

\section{Campbell, A.S.; McCracken, Ernest}

M. 1932.

Studies in forest resources in Florida. I. Timber Conservation, vol. 1., no. 3. II. The lumber industry, vol. 1. no. 4. III. The naval stores industry, vol. 1. no. 5. Gainesville, FL: University of Florida. 113, 84, and 105 p.

Campbell, R.S.; Cassidy, J.T. 1951. Grazing values for cattle on pine forest ranges in Louisiana. Bull. 452. Baton Rouge, LA: Louisiana Agricultural Experiment Station. $31 \mathrm{p}$. 
Campbell, W.A.; Copeland, O.L., Jr. 1954.

Littleleaf disease of shortleaf and loblolly pines. Circ. 940. Washington, DC: U.S. Department of Agriculture. $41 \mathrm{p}$.

\section{Chapman, H.H. 1942.}

Management of loblolly pine in the pine-hardwood region of Arkansas and Louisiana. Bull. 49. New Haven, CT: Yale University, School of Forestry. $150 \mathrm{p}$.

Chi, C.T.; Horn, D.A.; Rexnik, R.B., and others. 1979.

Source assessment: prescribed burning: state of the art. 600/2-79/0lgh. Washington, DC: Environmental Protection Agency. $107 \mathrm{p}$. [Available from the National Technical Information Service, 5285 Port Royal Road, Springfield, VA 22161.]

\section{Clepper, Henry. 1971.}

Professional forestry in the United States. Washington, DC: Resources for the Future. $337 p$.

Clutter, Jerome L.; Harms, William R.; Brister, Graham H.; Rheney, John W. 1984.

Stand structure and yields of site-prepared loblolly pine plantations in the lower coastal plain of the Carolinas, Georgia, and north Florida. Gen. Tech. Rep. SE-27. Asheville, NC: U.S. Department of Agriculture, Forest Service, Southeastern Forest Experiment Station. 173 p.
Coile, T.S.; Schumacher, F.X.1964. Soil-site relations, stand structure, andyields of slash and loblolly pine plantations. Durham, NC: T.S. Coile, Inc. 296 p.

\section{Cooper, R.W. 1973.}

Beneficial and detrimental effects of forest fires. In: Eighth annual meeting, Middle St. Interstate Forest Fire Protection Compact; [Dates of meeting unknown]; [Place of meeting unknown]. [Place of publication unknown]: [Publisher unknown]: 57-66.

\section{Cordell, H.K. 1979.}

The status and future of outdoor recreation on the South's private forests. In: 28th annual forest symposium; [Date of meeting unknown]; [Place of meeting unknown]. Baton Rouge, LA: Louisiana State University: 5-31.

Coster, Jack E.; Searcy, Janet L. 1979.

Evaluating control tactics for the southern pine beetle: symposium proceedings. Tech. Bull. 1613. Washington, DC: U.S. Department of Agriculture, Forest Service. $118 \mathrm{p}$.

Croker, C. Jr.; Boyer, W.D. 1975. Regenerating longleaf pine naturally. Res. Pap. SO-105. New Orleans, LA: U.S. Department of Agriculture, Forest Service, Southern Forest Experiment Station.

$21 \mathrm{p}$. 


\section{Crow, A. Bigler. 1982.}

Fire ecology and fire use in the pine forest of the South: chronological bibliography. Baton Rouge, LA: Louisiana State University. $131 \mathrm{p}$.

\section{Cushwa, C.T. 1968.}

Fire: a summary of literature on the U.S. from the mid 1920's to 1966. Asheville, NC: U.S. Department of Agriculture, Forest Service, Southeastern Forest Experiment Station. $117 \mathrm{p}$.

Davis, K.P. 1959.

Forest fire-control and use. New York: McGraw-Hill. 584 p.

Dinus, R.J.; Schmidt, R.A., and others. 1977.

Management of fusiform rust in southern pines: symposium proceedings; 1976 December 7-8; [Place of meeting unkonwn]. Gainesville, FL: University of Florida. $163 \mathrm{p}$.

Doolittle, W.L.; Welch, G.D. 1974.

Fire prevention in the South: personal contact pays off. Journal of Forestry. 72: $488-490$.

Dorman, Keith W. 1976.

The genetics and breeding of southern pines. Agric. Handb. 471. Washington, DC: U.S. Department of Agriculture. $407 \mathrm{p}$.

\section{Douglas, James E. 1981.}

Environmental impacts of weed control alternatives on water. In: Proceedings, 1981 John S. Wright Forestry Conference; [Date of meeting unknown]; [Place of meeting unknown]. West Lafayette, IN: Purdue University. $305 \mathrm{p}$.

\section{Douglas, James E.; Van Lear, David} H. 1983.

Prescribed burning and water of ephemeral streams in the Piedmont of South Carolina. Forest Science. 29: $181-189$.

Douglas, James E.; Van Lear, David H.; Valverde, Carmen. 1982.

Streamflow changes after prescribed burning and clearcutting pine stands in the South Carolina Piedmont. Gen. Tech. Rep. SE-24. Asheville, NC: U.S. Department of Agriculture, Forest Service, Southeastern Forest Experiment Station: $454-460$.

\section{Drew, John; Roberts, Donald R.} 1978.

Extractive enhancement in pines by paraquat treatment. Forest Processing Journal. 28(9): $21-26$.

Duerr, W.A.; Fedkiw, John; Guttenberg, Sam. 1956.

Financial maturity: a guide to profitable timber growing. Tech. Bull. 1146. Washington, DC: U.S. Department of Agriculture. $47 \mathrm{p}$. 
Duncan, D.W.; Epps, E.A., Jr. 1958. Minor mineral elements and other nutrients on forest ranges in Louisiana. Bull. 516. Baton Rouge, LA: Central Louisiana Agriculture Experiment Station. $19 \mathrm{p}$.

Dunkelberger, J.E.; Altobellis, A.T. 1975.

Profiling the woodburner. Bull. 469. Auburn, AL: Alabama Agriculture Experiment Station. $35 \mathrm{p}$.

\section{Dutrow, G.F. 1978.}

Economic management opportunities to increase timber supplies in the Southern U.S. In: Proceedings on complete tree utilization of southern pines; [Date of meeting unknown]; [Place of meeting unknown]. Madison, WI: Forest Products Research Society: $6-14$.

Duvall, V.L.; Whitaker, L.B. 1964. Rotation burning: a forage management system for long-leaf pine-bluestem ranges. Journal of Range Management. 17: 3226.

Esser, Mary H., comp., ed. 1979. Sixth annual lightwood research conference Proceedings. Asheville, NC: U.S. Department of Agriculture, Forest Service, Southeastern Forest Experiment Station. $151 \mathrm{p}$.
Fairchild, Fred Roger. 1935.

Forest taxation in the United States. Misc. Publ. 218. Washington, DC. U.S. Government Printing Office. $681 \mathrm{p}$.

Farrar, R.M. 1979.

Status of growth and yield information in the South. Southern Journal of Applied Forestry. 5: $162-166$.

Feduccia, D.P.; Mann, W.F., Jr. 1976.

Black turpentine beetle infestation after thinning in a loblolly pine plantation. Res. Note SO-206. New Orleans, LA: U.S. Department of Agriculture, Forest Service, Southern Forest Experiment Station. 3 p.

Fight, Roger D.; Dutrow, G.F. 1981. Financial comparisons of forest fertilization in the Pacific Northwest and the Southeast. Journal of Forestry. 79: 214-215.

Folweiler, A.D.; Brown, A.A. 1939. Fire in the forests of the United States. Baton Rouge, LA: Louisiana State University. $164 \mathrm{p}$.

\section{Foster, A.A. 1961.}

Control of black root rot of pine seedlings by soil fumigation in the nursery. Rep. 8. Macon, GA: Georgia Forestry Research Council. $5 \mathrm{p}$. 
Franklin, E. Carlyle, ed. 1981. Pollen management handbook. Agric. Handb. 587. Washington, DC: U.S. Department of Agriculture. $98 \mathrm{p}$.

Froehlich, R.C.; Kuhlman, E.G.; Hodges, C.S.; Weiss, M.J.; Nichols, Gau. 1977.

Fomes annosus root rot in the South: guidelines for prevention. New Orleans, LA: U.S. Department of Agriculture, Forest Service, Southern and Southeastern Forest Experiment Stations and State and Private Forestry. 17 p.

\section{Geary, T.E.; Meskimen, G.F.;}

Franklin, E.C. 1983.

Growing eucalypts in Florida for industrial wood products. Gen.

Tech. Rep. SE-23. Asheville, NC: U.S. Department of Agriculture, Forest Service, Southeastern Forest Experiment Station. $43 \mathrm{p}$.

Greene, Smith W. 1931.

Effect of annual grass fires and organic matter and other constituents of virgin longleaf pine soils. Journal of Agricultural Research. U-50(10).

\section{Grelen, Harold E. 1983.}

Comparisons of seasons and frequencies of burning in a young slash pine plantation. Res. Pap. SO-185. New Orleans, LA: U.S. Department of Agriculture, Forest Service, Southern Forest Experiment Station. $5 \mathrm{p}$.
Grosenbaugh, L.R. 1958.

Point-sampling and linesampling: probability theory, geometric implications, synthesis. Res. Pap. SO-160. New Orleans, LA: U.S. Department of Agriculture, Forest Service, Southern Forest Experiment Station. $34 \mathrm{p}$.

Guldin, Richard W. 1983.

Regeneration costs using container-grown southern pine seedlings. Res. Pap. SO-187. New Orleans, LA: U.S. Department of Agriculture, Forest Service, Southern Forest Experiment Station. $29 \mathrm{p}$.

\section{Guldin, Richard W.; Barnett,} James P., eds. 1981.

Proceedings of the southern containerized forest tree seedling conference; 1980 August 25-21; Savannah, GA. Gen. Tech. Rep. SO-37. New Orleans, LA: U.S. Department of Agriculture, Forest Service, Southern Forest Experiment Station. $156 \mathrm{p}$.

\section{Halls, L.K. 1969.}

White-tailed deer in the southern forest habitat. In: Proceedings of a symposium; 1969 March 25-26, Nacogdoches, TX. New Orleans, LA: U.S. Department of Agriculture, Forest Service, and the Wildlife Society and Stephen F. Austin State University. 130 p. 
Halls, L.K.; Boyd, Charles E. 1982. Influence of managed pine stands and mixed pine/hardwood stands on well being of deer. Res. Pap. SO-183. New Orleans, LA: U.S. Department of Agriculture, Forest Service, Southern Forest Experiment Station. $22 \mathrm{p}$.

Halls, L.K.; Duvall, V.L. 1961. Projects and costs of forest grazing. Forest Farmer. 20(7): $157-162$

Halls, L.K.; Hughes, R.H.; Peevy, F.A. 1960.

Grazed firebreaks in southern forests. Inf. Bull. 226. Washington, DC: U.S. Department of Agriculture. $8 \mathrm{p}$.

Hamel, Paul B.; Legrand, Harry E., Jr.; Lemnantz, Michael R.;

Gauthreux, Sidney A., Jr. 1982.

Bird-habitat relationships on southeastern forest lands. Gen.

Tech. Rep. SE-22. Asheville, NC: U.S. Department of Agriculture, Forest Service. $417 p$.

\section{Harper, V.L. 1944.}

Effects of fire on gum yields of longleaf and slash pines. Tech. Bull. 494. Washington, DC: U.S. Department of Agriculture. $32 \mathrm{p}$
Hastings, Felton L.; Coster, Jack

E. 1981.

Field and laboratory evaluations of insecticides for southern pine beetle control. Tech. Rep. SE-21. Asheville, NC: U.S. Department of Agriculture, Forest Service, Southeastern Forest Experiment Station. $40 \mathrm{p}$.

\section{Hepting, G.H. 1935.}

Decay following fire on young Mississippi delta hardwoods. Tech. Bull. 494. Washington, DC: U.S. Department of Agriculture. $32 \mathrm{p}$.

\section{Hepting, G.H. 1971.}

Diseases of forest and shade trees. [Place of publication unknown]: [Publisher unknown]. [Pagination unknown].

Heyward, F.D.; Barrette, R.M. 1934. Effect of frequent fires on chemical composition of forest soils in the long-leaf pine region. Bull. 265. Gainesville, FL: Florida Agricultural Experiment Station. $39 \mathrm{p}$.

Hewlett, John D. 1983.

Forests and water quality. Athens, GA: University of Georgia, School of Forest Resources. 
Hooper, Robert G.; Robinson, Andrew F., Jr.; Jackson, Jerome A. 1980.

The red-cockaded woodpecker. Gen. Rep. SA-GR9. Atlanta, GA: U.S. Department of Agriculture, Forest Service, Southeastern Area, State and Private Forestry. $8 \mathrm{p}$.

Hopkins, W. 1951.

Wood logs vs. pine logs. [Place of publication unknown]: Louisiana Forestry Association. $14 \mathrm{p}$.

Johansen, Ragner W.; McNab, W.H. 1982.

Prescribed burning on large land holdings in the South during 1975. Res. Note SE-316. Asheville, NC: U.S. Department of Agriculture, Forest Service, Southeastern Forest Experiment Station. 4 p.

Johnson, E.W. 1973.

Relationship between point density measurements and subsequent growth of southern pine. Bull. 447. Auburn, AL: Alabama Agricultural Experiment Station. $109 \mathrm{p}$.

\section{Johnson, R.L. 1970.}

Renewing hardwood stands on bottom lands and loess. In: Silviculture and management of southern hardwoods; 19th annual forest symposium, proceedings; [Dates of meeting unknown]; Baton Rouge, LA. Baton Rouge, LA: Louisiana State University: 113-121.
Koch, Peter. 1972.

Utilization of the southern pines. Agric. Handb. 420. (2 vols.) Washington, DC: U.S. Department of Agriculture. 734 and 1663 p.

\section{Koger, Jerry L.; Webster, Dennis}

B. 1984.

L-O-S-T: Logging Optimization Selection Technique. Res. Pap. SO-203. New Orleans, LA: U.S. Department of Agriculture, Forest Service, Southern Forest Experiment Station. 66 p.

\section{Kormarek, E.V. 1981.}

Proceedings of conference on wildlife impacts. Tall Timbers Research Station Prescribed Fire and Wildlife; 1981. [Place of publication unknown]: [Publisher unknown]. [Pagination unknown].

KuhIman, E.G.; Hodges, C.S.;

Froehlich, R.C. 1976.

Minimizing losses to Fomes annosus in the Southern United States. Res. Pap. SE-151. Asheville, NC: U.S. Department of Agriculture, Forest Service, Southeastern Forest Experiment Station. $16 \mathrm{p}$.

\section{Langdon, Gordon O.; Bennett,}

Frank A. 1976.

Management of natural stands of slash pine. Res. Pap. SE-147. Asheville, NC: U.S. Department of Agriculture, Forest Service, Southeastern Forest Experiment Station. $12 \mathrm{p}$. 
Lantz, Clark, comp. 1984.

Proceedings, 1984 southern nursery conferences; 1984 June 11-14 and July 24-27; Alexandria, LA, and Asheville, NC. Atlanta, GA: U.S. Department of Agriculture, Forest Service, Southern Region.

$224 p$.

\section{Larson, Robert; Goforth, Marcus.}

\section{4.}

TRAS and timber volume projection model. Tech. Bull. 1508. Washington, DC: U.S. Department of Agriculture, Forest Service. $15 \mathrm{p}$.

\section{Lawson, E.R. 1979.}

Natural regeneration of shortleaf pine. In: Proceedings: symposium for the management of pines of the interior South. Tech. Publ. SA-TP2. Atlanta, GA: U.S. Department of Agriculture, Forest Service: $1-6$.

Lewis, Clifford E. 1983.

Forage resources and integrated management in the slash pine ecosystem. In: Symposium on the managed slash pine ecosystem; 1981 June 9-11; Gainesville, FL. Gainesville, FL: University of Florida. 1983: [Pagination unknown].

Lockard, C.R.; Putnam, J.A.; Carpenter, R.D. 1950.

Log defects in southern hardwoods. Agric. Handb. 4. Washington, DC: U.S. Department of Agriculture. $37 \mathrm{p}$.
Maisenhelder, L.C. 1960.

Cottonwood plantation for southern bottom lands. Occas. Pap.

179. New Orleans, LA: U.S.

Department of Agriculture, Forest Service, Southern Forest Experiment Station. 24 p.

Mann, W.F., Jr.; Derr, H.J. 1964.

Guides for direct-seeding slash pine. Res. Pap. SO-12. New Orleans, LA: U.S. Department of Agriculture, Forest Service, Southern Forest Experiment Station. $27 \mathrm{p}$.

Mann, W.F., Jr.; Hayes, M.J. 1978. Status of some new herbicides. Gen. Tech. Rep. SO-21. New Orleans, LA: U.S. Department of Agriculture, Forest Service, Southern Forest Experiment Station. $17 \mathrm{p}$.

Marlin, Clifton B. 1978.

A study of owners of small timber tracts in Louisiana. Bull. 710. Baton Rouge, LA: Louisiana Agricultural Experiment Experiment Station. $65 \mathrm{p}$.

Marx, D.H.; Ruelle, J.L.; Kenney, A.J., and others. 1982.

Commercial inoculum of Pisolithus tinctorius on container grown seedlings. Forest Science. 28: $373-400$. 
McKee, William, Jr.; Lewis, Clifford E. 1982a.

Changes in soil fertility following prescribed burning on coastal plain sites. Res. Pap. SE-234. Asheville, NC: U.S. Department of Agriculture, Forest Service, Southeastern Experiment Station. $23 \mathrm{p}$.

McKee, William, Jr.; Lewis, Clifford E. 1982b.

Influence of burning and grazing on soil nutrient properties and tree growth in a Georgia coastal plain site after 40 years. In: Proceedings of the $2 \mathrm{~d}$ biennial southern silvicultural research conference; 1982 November 4-5; Atlanta, Ga. Gen. Tech. Rep. SE-24. Asheville, NC: U.S. Department of Agriculture, Forest Experiment Station: 79-85.

McMillin, C.W., ed. 1978.

Complete tree utilization of southern pine: proceedings of a symposium; 1978 April 17-19; New Orleans, LA. Madison, WI: Forest Products Research Society. $484 \mathrm{p}$.

Meginnis, H.G. 1935.

Effect of cover on surface runoff and erosion in the loessial uplands of Mississippi. Agric. Circ. 347. Washington, DC: U.S. Department of Agriculture. $16 \mathrm{p}$.
Merkel, Edward P.; Clark, E.W. 1981.

Insecticides for preventing insectcaused mortality of paraquattreated slash pines. Res. Pap. SE-219. Asheville, NC: U.S. Department of Agriculture, Forest Service, Southeastern Forest Experiment Station. $7 \mathrm{p}$.

Mesavage, C.; Girard, J.W. 1946. Tables for estimating board foot volumes of timber. Washington, DC: U.S. Department of Agriculture. 94 p.

Mexal, J.G.; Snow, G.A. 1978. Seed treatment with systemic fungicides for the control of fusiform rust in loblolly pine. Res. Note SO-238. New Orleans, LA: U.S. Department of Agriculture, Forest Service. $4 p$.

Miller, W. Frank. 1976.

Physical and chemical properties of forested soils. Bull. 734. Starkville, MS: Mississippi Agricutural Experiment Station. 112 p.

\section{Moore, William H.; Terry, W.S.} 1981.

Short duration grazing may improve wildlife habitat in southeastern pine lands. Proceedings $33 d$ annual conference, Southeast Association of Fish and Wildlife Agencies; 1979 October $21-24$; Hot Springs, AR. [Place of publication unknown]: Southeast Association of Fish Wildlife Agencies: 279-287. 
Nelson, Charles A. 1971.

History of the U.S. Forest Products Laboratory 1910-1963). Madison, WI: U.S. Department of Agriculture, Forest Service, Forest Products Laboratory. $177 \mathrm{p}$.

Nord, John C.; Flavell, Thomas H.; Pepper, William D.; Layman, Harry F. 1978.

Field test of four insecticides for control of pales and pitcheating weevils in first-year pine plantations. Res. Note SE-255. Asheville, NC: U.S. Department of Agriculture, Forest Service, Southeatern Forest Experiment Station. $9 \mathrm{p}$.

Paul, James T.; Clayton, Joe, comps. 1978.

User manual: forestry weather interpretation system (WIS). Asheville, NC: U.S. Department of Agriculture, Forest Service, Southeastern Forest Experiment Station and Southeastern Area, State and Private Forestry, and the U.S. National Weather Service. $83 \mathrm{p}$.

\section{Pearson, H.A. 1980.}

Livestock in multiple use management of southern forest range. In: Proceedings, southern forest ranges and pasture resource symposium; 1980 May 13-14; New Orleans, LA. Morrilton, AR. Winrock International: 75-88.
Peevy, F.A. 1976.

Timber stand improvement-tree injection and pellets. In: Byrnes, U.R.; Holt, Harvey A., eds. Herbicides in forestry: John S. Wright Forestry, Conference proceedings; 1976 February $3-5$; West Lafayette, IN. West Lafayette, IN: Purdue University: 85-92.

Pomeroy, Kenneth B.; Yoho, James G. 1964.

North Carolina lands: ownership use, and management of forests and related lands. Washington, DC: American Forestry Association. $372 \mathrm{p}$.

Powers, H.R., Jr.; Kraus, John F.; Duncan, H.J. 1979.

A seed orchard for rust resistant, pines-progress and promise. Res. Rep. 1. Macon, GA: Georgia Forestry Commission. $8 p$.

Prewitt, E. Lavalle, Jr. 1982. The silviculture of southern hardwoods. In: Proceedings of the Society of American Foresters national convention: 1981 September 19-22; Cincinnati, $\mathrm{OH}$. Bethesda, MD: Society of American Foresters: 24-27.

Putnam, J.A. 1951.

Management of bottomland hardwoods. Occas. Pap. 116. New Orleans, LA: U.S. Department of Agriculture, Forest Service, Southern Forest Experiment Station. $60 \mathrm{p}$. 
Putnam, J.A.; Bull, H. 1932.

The trees of the bottomlands of the Mississippi River Delta. Gen. Pap. 27. New Orleans, LA: U.S. Department of Agriculture, Forest Service, Southern Forest Experiment Station.

$207 \mathrm{p}$.

\section{Pyne, Stephen J. 1982.}

Fire in America: a cultural history of wildland and rural fire. Princeton, NJ: Princeton University Press. $654 \mathrm{p}$.

Randall, J.K. 1973.

Superior cottonwoods developed at the delta station. Mississippi Agriculture Experiment Station Research Highlight 37(7): 1-5.

Rawlins, N.O.; Sorensen, H.B. 1968.

An analysis of the production and marketing structure of southern pulpwood. Austin, TX: Texas Agricultural Experiment Station. $24 \mathrm{p}$.

\section{Reynolds, R.R. 1980.}

The Crossett story: the beginning of forestry in southern Arkansas and northern Louisiana. Gen. Tech. Rep. SO-32. New Orleans, LA: U.S Department of Agriculture, Forest Service, Southern Forest Experiment Station. $40 \mathrm{p}$.

Richter, D.D.; Ralston, C.W.; Harms, W.R. 1982.

Prescribed fire: effects on water quality and forest nutrient cycling. Science. 215: 661-663.

\section{Risbrudt, Christopher D.;}

Ellefson, Paul V. 1983.

An economic evaluation of the 1979 forest incentives program. Sta. Bull. 550. St. Paul, MN: University of Minnesota Agriculture Experiment Station. $55 \mathrm{p}$.

\section{Row, Clark; Fasick, Clyde; Guttenberg, Sam. 1965.} Improving sawmill profits through operations research. Res. Pap. SO-20. New Orleans, LA: U.S. Department of Agriculture, Forest Service, Southern Forest Experiment Station.

$26 \mathrm{p}$.

\section{Rowan, S.J. 1979.}

Rainfall and frequency of ferbam sprays important for fusiform rust control. Southern Journal of Applied Forestry. 3(4): 167-168.

\section{Scheffer, T.C.; Lindgren, R.M.} 1940.

Stains of sapwood and sapwood products and their control. Tech. Bull. 714. Washington, DC: U.S. Department of Agriculture. $124 \mathrm{p}$.

Schiff, Ashley R. 1962.

Fire and water. Cambridge, MA: Harvard University Press. 225 p.

Schumacher, F.X.; Chapman, R.A. 1942.

Sampling methods in forestry and range management. Bull. 7 . Raleigh-Durham, NC: Duke University School of Forestry. $213 p$.

Schumacher, F.X.; Coile, T.S. 1960. Growth and yield of natural stands of the southern pines. Durham, NC: T.S. Coile, Inc. 115 p. 
Shea, John P. 1940.

Getting at the roots of man-caused forest fires. Washington, DC:

U.S. Department of Agriculture, Forest Service. $78 \mathrm{p}$.

Siggers, P.V. 1944.

The brown spot needle blight of pine seedlings. Tech. Bull. 870 . Washington, DC: U.S. Department of Agriculture. 36 p.

Sluder, Earl R. 1980.

A study of geographic variations in loblolly pine in Georgia - 20th-year results. Res. Pap. SE-213. Asheville, NC: U.S. Department of Agriculture, Forest Service, Southeastern Forest Experiment Station. $30 \mathrm{p}$.

Snyder, E.M.; Derr, H.J. 1972. Breeding longleaf pines for resistance to brown spot needle blight. Phytology. 62: 325-327.

\section{Southeastern Forest Experiment} Station. 1983.

Directory of research programs. Asheville, NC: U.S. Department of Agriculture, Forest Service, Southeastern Forest Experiment Station. $14 \mathrm{p}$.

\section{Southern Forest Fire Laboratory.} 1976.

Southern forests smoke management guide. Gen. Tech. Rep. SE-10. Asheville, NC: U.S. Department of Agriculture, Forest Service, Southeastern Forest Experiment Station. $140 \mathrm{p}$.
Southern Forest Resource Analysis Committee. 1969.

The South's third forest. [Place of publication unknown]: Southern Forest Resource Analysis Committee. $111 \mathrm{p}$.

Stephen, F.M.; Searcy, J.L.; Hertel, G.D., eds. 1980.

Modeling southern pine beetle populations. Tech. Bull. 1630. Washington, DC: U.S. Department of Agriculture, Forest Service. $174 \mathrm{p}$.

\section{Stoddard, H.L. 1931.}

The bobwhite quail: its habits, preservation and increase. New York: Charles Scribner and Sons. $559 \mathrm{p}$.

\section{Stone, E.L., ed. 1983.}

The management slash pine ecosystem: proceedings of a symposium; 1981 June 9-11; Gainesville, FL. Gainesville, FL: University of Florida. $434 \mathrm{p}$.

Stubbs, Jack; Roberts, Donald R.;

Outcalt, Kenneth W. 1984.

Chemical stimulation of lightwood in southern pines. Gen. Tech. Rep. SE-25. Asheville, NC: U.S. Department of Agriculture, Forest Service, Southeastern Forest Experiment Station. $51 \mathrm{p}$.

Swaine, K.M.; Remion, M.C. 1981. Direct control methods for the southern pine beetle. Agric. Handb. 515. Washington, DC: U.S. Department of Agriculture. $15 \mathrm{p}$. 
Swindel, B.F., and others. 1983.

Multi-resource effects of harvest, site preparation and planting, pines flat woods. Southern Journal of Applied Forestry. 7(1):

6-15.

Thatcher, Robert C.; Searcy, Janet L.; Coster, Jack E.; Hertel, Gerard D. [1980].

The southern pine beetle. Tech. Bull. 1631. Washington, DC: U.S. Department of Agriculture. 266 p.

\section{U.S. Department of Agriculture.} 1935.

A naval stores handbook dealing with the production of pine gum or oleoresin. Misc. Publ. 201.

Washington, DC: U.S. Department of Agriculture. 201 p.

\section{U.S. Department of Agriculture.} 1981.

Southern pine beetle program accomplishments report. Agric. Inf. Bull. 438. Washington, DC:

U.S. Department of Agriculture. $23 \mathrm{p}$.

\section{U.S. Department of Agriculture,} Forest Service. 1971.

Prescribed burning symposium proceedings; 1971 April 14-16;

Charleston, SC. Asheville, NC:

U.S. Department of Agriculture, Forest Service, Southeastern Forest Experiment Station. 160 p.
U.S. Department of Agriculture, Forest Service. 1978a.

National fire effects workshop; 1978 April 10-14; Denver, CO.

Gen. Tech. Rep. WO-13. Washington, DC: U.S. Department of Agriculture, Forest Service. 64 p.

\section{U.S. Department of Agriculture,}

\section{Forest Service. 1978b.}

Integrated inventories of renewable natural resources: proceedings of the workshop; 1978 January 8-12; Tucson, AZ. Gen. Tech. Rep. RM-55. Fort Collins, CO: U.S. Department of Agriculture, Forest Service, Rocky Mountain Forest and Range Experiment Station. $482 \mathrm{p}$.

\section{U.S. Department of Agriculture,} Forest Service. 1978c.

Structural flakeboard from forest residues. Gen. Tech. Rep. WO-5. Washington, DC: U.S. Department of Agriculture, Forest Service.

$241 \mathrm{p}$.

\section{U.S. Department of Agriculture,} Forest Service. 1980a.

Mid-South upland hardwood symposium for the practicing forester and land manager: proceedings; 1980 April 30-May 2; Harrison, AR. Tech. Publ. SA-TP-12. Atlanta, GA: U.S. Department of Agriculture, Forest Service, Southeastern Area, State and Private Forestry. $186 \mathrm{p}$. 
U.S. Department of Agriculture, Forest Service. 1980b.

Forest insect and disease conditions in the South. For. Rep.

SA-FR-17. Atlanta, GA: U.S.

Department of Agriculture, Forest

Service, Southeastern Area, State and Private Forestry.

\section{U.S. Department of Agriculture,}

Forest Service. 1982a.

An analysis of the timber situation in the United States, 1952-2030, For. Resour. Rep. 23. Washington, DC: U.S. Department of Agriculture. 499 p.

\section{U.S. Department of Agriculture, Forest Service. $1982 \mathrm{~b}$.} 1980-1990 National program of research for forests and associated rangelands. Gen. Tech. Rep. WO-32. Washington, DC: U.S. Department of Agriculture, Forest Service. $60 \mathrm{p}$.

\section{U.S. Department of Agriculture,}

\section{Forest Service. 1984a.}

Southern pine nursery handbook. Atlanta, GA: U.S. Department of Agriculture, Forest Service, Southern Region.

\section{U.S. Department of Agriculture,}

\section{Forest Service. 1984b.}

Pesticide background statements. Vol. 1. Herbicides. Agric. Handb. 633. Washington, DC: U.S. Department of Agriculture, Forest Service.
U.S. Department of Agriculture, Forest Service. 1985.

Insects of eastern forests. Misc.

Publ. 1426. Washington, DC:

U.S. Department of Agriculture, Forest Service.

U.S. Forest Service, Office of Experiment Stations, and Cooperating Agencies. 1929.

Volume, yield, and stand tables for second-growth southern pines. Misc. Publ. 50. Washington, DC: U.S. Department of Agriculture, Forest Service. $56 p$.

University of Georgia. 1983.

Proceedings of the 17 th southern forest tree improvement conference; 1983 June 6-9; Athens, GA. Athens, GA: University of Georgia. 375 p. [Available from National Technical Information Service, 5285 Port Royal Road, Springfield, VA 22161.]

Verrall, Arthur F. 1982.

A history of forest pathology in the South and Southeast. Gen. Tech. Rep. SO-36. New Orleans, LA: U.S. Department of Agriculture, Forest Service. 200 p.

Wahlenberg, W.G. 1946.

Longleaf pine. Washington, DC: Pack Forestry Foundation in cooperation with U.S. Forest Service. $429 p$.

Wahlenberg, W.G. 1960. Loblolly pine. Raleigh-Durham, NC: Duke University, School of Forestry. $603 \mathrm{p}$. 
Wahlenberg, W.G., ed. 1965.

A guide to loblolly and slash pine management in the Southeastern United States. Rep. 14. Macon, GA: Georgia Forest Research Council. $360 \mathrm{p}$.

Wahlenberg, W.G.; Reed, H.R. 1939.

Effects of fire and cattle grazing on longleaf pine lands as studies at McNeill, Mississippi. Tech.

Bull. 683. Washington, DC: U.S.

Department of Agriculture. $52 \mathrm{p}$.

Wakeley, P.C. 1935.

Artificial reforestation in the soutiern pine region. Tech. Bull. 492. wishington, DC: U.S.

Department of Agriculture. $114 \mathrm{p}$.

Wakeley, P.C. 1951.

Planting the southern pines. 3 vols. Occas. Pap. 122. Washington, DC: U.S. Department of Agriculture. 579 p.

Wakeley, P.C. 1954.

Planting the southern pines. Monogr. 18. Washington, DC:

U.S. Department of Agriculture. $233 \mathrm{p}$.

Walker, Lawrence C. 1972.

Silvicultural of southern upland hardwoods. Bull. 22. Nacogdoches, TX: Stephen F. Austin State University. $137 \mathrm{p}$.
Wells, Carol G. 1977.

Nutrient cycling and its relationship to fertilization. In: Proceedings, southern forest soils workshop; 1976 October 19-21; Charleston, SC. Atlanta, GA: U.S. Department of Agriculture, Forest Service, Southeastern Area, State and Private Forestry: $78-89$.

Wells, O.O., and others. 1978. Shortleaf and slash pine hybrids outperform parents in parts of the Southeast. Southern Journal of Applied Forestry. 2(1): 28-32.

White, Roy R. 1961.

Austin Carey, the father of southern forestry. Forest History. 5(1): $2-5$.

Wood, Gene W., ed. 1981. Prescribed fire and wildlife in southern forests. Georgetown, SC: Belle W. Barruck Forest Science Institute. $170 \mathrm{p}$.

Zobel, Bruce; Talbert, John. 1984. Applied forest tree improvement. Philadelphia: John Wiley and Sons. 505 p.

\section{Literature Cited - Unpublished}

Wakeley, Philip C. 1964.

A biased history of the Southern Forest Experiment Station through fiscal year 1933. [Typed manuscript, available from the USDA Forest Service, Southern Forest Experiment Station, 701 Loyola Avenue, New Orleans, LA 70113.] 


